\title{
Long-term measurements of aerosol optical properties and radiative forcing (2011-2017) over Central Amazonia
}

\author{
Rafael da Silva PALÁCIOS ${ }^{1 *}$, Paulo ARTAXO ${ }^{2}$, Glauber Guimarães CIRINO ${ }^{1}$, Valeria NAKALE ${ }^{1}$, \\ Fernando Gonçalves de MORAIS ${ }^{2}$, Lucas Douglas ROTHMUND ${ }^{3}$, Marcelo Sacardi BIUDES ${ }^{3}$, \\ Nadja Gomes MACHADO ${ }^{4}$, Leone Francisco Amorim CURADO ${ }^{3}$, \\ João Basso MARQUES ${ }^{3}$ and José de Souza NOGUEIRA ${ }^{3}$
}

\author{
${ }^{1}$ Federal University of Pará, UFPA, Belém 66075-110, Brazil. \\ ${ }^{2}$ University of São Paulo, USP, São Paulo 05508-090, Brazil. \\ ${ }^{3}$ Federal University of Mato Grosso, UFMT, Cuiabá 78060-900, Brazil. \\ ${ }^{4}$ Federal Institute of Mato Grosso, IFMT, Cuiabá 78050-560, Brazil. \\ * Corresponding author: rafael.pgfa@gmail.com
}

Received: April 23, 2020; accepted: August 20, 2020

\begin{abstract}
RESUMEN
La región del Amazonas es una de las áreas continentales más impolutas, cuyas concentraciones de gases traza atmosféricos y partículas de aerosol son muy bajas, sobre todo en la estación húmeda. El presente estudio proporciona resultados observacionales in situ tanto de las características ópticas y radiativas como de la columna atmosférica de los aerosoles en un bosque virgen de la Amazonia Central. Se evaluó la variación espectral de las propiedades de los aerosoles (profundidad óptica de aerosoles [AOD, por sus siglas en inglés], albedo de dispersión simple [SSA] y parámetro de asimetría [AP]) utilizando para ello datos de la Red Robótica de Aerosoles (AERONET). Los valores de SSA en condiciones naturales de la columna atmosférica (obtenidos de AERONET) se compararon con valores de SSA obtenidos de mediciones in situ. Se estimaron los valores del forzamiento radiativo de onda corta (SWARF) en el techo de la atmósfera (TOA) y en la superficie (SUR) con datos del modelo SBDART y se validaron con valores de AERONET utilizando análisis de regresión. Los valores de SWARF tuvieron una alta correlación con los de TOA (0.97) y SUR (0.92), incluyendo las temporadas húmeda y seca. Los valores promedio mensuales, estacionales y anuales de $\mathrm{SWARF}_{\text {TOA }}$ y SWARF $\mathrm{SUR}_{\text {SU }}$ fueron negativos, en tanto que los de $\mathrm{SWARF}_{\mathrm{ATM}}$ fueron positivos. Los valores de $\mathrm{SWARF}_{\mathrm{TOA}}$ fueron de $-9.18 \pm 2.80 \mathrm{~W} \mathrm{~m}^{-2}$ y los de $\mathrm{SWARF}_{\mathrm{SUR}}$ de $-20.77 \pm 5.04 \mathrm{~W} \mathrm{~m}^{-2}$ en la estación seca, induciendo una tasa de calentamiento (HR) de $0.37 \pm 0.13 \mathrm{~K} \mathrm{día}^{-1}$. El presente estudio muestra que, para series largas de medición, los efectos ocasionados por los aerosoles en el flujo radiativo en un bosque virgen de la Amazonia Central fueron del orden de $-3.66 \pm 1.59 \mathrm{~W} \mathrm{~m}^{-2}$ para $\mathrm{SWARF}_{\mathrm{TOA}} \mathrm{y}$ de $-11.86 \pm 2.35 \mathrm{~W} \mathrm{~m}^{-2}$ para $\mathrm{SWARF}_{\text {SUR }}$ durante la temporada húmeda.
\end{abstract}

\begin{abstract}
The Amazon region is one of the most pristine continental areas whose concentrations of atmospheric trace gases and aerosol particles are very low, mainly in the wet season. This study provides observational results of aerosol optical and radiative characteristics in situ as well as atmospheric columnar at a pristine forest in Central Amazonia. Spectral variation of the aerosol properties (aerosol optical depth [AOD], single scattering albedo [SSA], and asymmetry parameter [AP]) was evaluated using the AErosol RObotic NETwork (AERONET) data. The SSA values under natural atmospheric column conditions (AERONET) were compared to the SSA values calculated with in situ measurements. The values of shortwave aerosol radiative forcing (SWARF) on top of the atmosphere (TOA) and the surface (SUR) were estimated using the SBDART model and were validated with the AERONET values with regression analysis. SWARF had a high correlation to
\end{abstract}


TOA (0.97) and SUR (0.92), including dry and wet seasons. Monthly, seasonal and annual mean values of $\mathrm{SWARF}_{\mathrm{TOA}}$ and $\mathrm{SWARF}_{\mathrm{SUR}}$ were negative while $\mathrm{SWARF}_{\mathrm{ATM}}$ values were positive. $\mathrm{SWARF}_{\mathrm{TOA}}$ was -9.18 $\pm 2.80 \mathrm{~W} \mathrm{~m}^{-2}$ and $\mathrm{SWARF}_{\text {SUR }}$ was $-20.77 \pm 5.04 \mathrm{~W} \mathrm{~m}^{-2}$ in the dry season, inducing a heating rate (HR) of $0.37 \pm 0.13 \mathrm{~K}$ day $^{-1}$. This study showed that, for a long series of measurements, the effects caused by aerosols on the radiative flux in the pristine forest of Central Amazonia were of the order of SWARF TOA of $-3.66 \pm$ $1.59 \mathrm{~W} \mathrm{~m}^{-2}$ and $\mathrm{SWARF}_{\mathrm{SUR}}$ of $-11.86 \pm 2.35 \mathrm{~W} \mathrm{~m}^{-2}$ during the wet season.

Keywords: single scattering albedo, aerosol radiative forcing, rainforest, heating rate.

\section{Introduction}

The impacts caused by atmospheric aerosols on climate change have received special attention during the last decades (IPCC, 2013). Aerosols affect the radiation budget, altering Earth's climate by absorbing and scattering radiation (direct radiative effect), acting as clouds condensation nuclei, and modifying their physical properties (indirect radiative effect) (Ramanathan et al., 2001; Kaufman et al., 2005; Scott et al., 2018a). The aerosol effects (direct and indirect) have large regional variations, mainly due to short lifetime, complex chemical composition, and interaction in the atmosphere, resulting in high space-temporal heterogeneities (Rajeev and Ramanathan, 2001). Different regions, characterized by different aerosol sources as well as different meteorological conditions can provide important information on the radiative effects of aerosols at a regional and global scale (Artaxo et al., 2013; Hooda et al., 2016; Martin et al., 2016; Bibi et al., 2017).

The terrestrial biosphere is an important source of natural aerosols (Hallquist et al., 2009; Carslaw et al., 2010; Scott et al., 2018a, b). These natural sources (biogenic volatile organic compounds) can dominate ambient aerosol in the tropics (Pöschl et al., 2010; Martin et al., 2010, 2016). Because natural aerosol constitutes a large fraction of ambient aerosol, it can have important radiative effects (Rap et al., 2013; Rizzo et al., 2013; Scott et al., 2014). The Amazon basin is a great "laboratory" for studying atmospheric processes characteristic of natural conditions, as they existed before the impact of industrialization in the regional and global atmosphere (Andreae, 2007; Artaxo et al., 2013; Martin et al., 2016; Rizzo et al., 2018). It is a key ecosystem to understand the climate system, but its forest area has been decreasing due to deforestation, which began to reach substantial levels in the mid-1970s and continues incessantly until the present day (Andreae et al., 2002; Schafer et al., 2008; Scott et al., 2018b).

The concentration of aerosol in the Amazon is about 300-500 particles per $\mathrm{cm}^{3}$ (Martin et al., 2010), which represents an upper limit to the natural atmospheric particle loading before anthropogenic influence (Andreae, 2007; Artaxo et al., 2013; Rizzo et al., 2018). However, the most preserved forest in the region is seasonally influenced by anthropogenic emissions of the biomass burning due to expansion of agriculture, logging, urbanization (Davidson et al., 2012); also, by long-range transport, which contributes with particles from outside the basin (Andreae et al., 2015). Thus, the characterization of the optical and radiative aerosol properties of the Amazon in clean and polluted conditions is crucial to our understanding of the dynamic biosphere-atmosphere processes and the resilience of the ecosystem to changes (Artaxo et al., 2013).

Aerosol radiative forcing (ARF) is the net change in the energy balance of the Earth's system due to some forced disturbance in any atmosphere layer (Ramanathan et al., 2001; Singh et al., 2016). Impacts on the radiation balance vary according to the region, hence a comprehensive examination of the optical and radiative properties of aerosols at a local and regional level is necessary (Rajeev and Ramanathan, 2001; Kaufman et al., 2002; Prasad et al., 2007; Bibi et al., 2017). ARF is influenced by the aerosol optical depth (AOD), single scattering albedo (SSA), and the asymmetry parameter (AP) (Sena et al., 2013). The SSA is the most important parameter that affects ARF and is extremely sensitive to the processes of absorption and scattering of the aerosols in the atmosphere (Bibi et al., 2017). Small errors in the estimation of SSA can affect ARF signal (Takemura et al., 2002). The intensity and sign of ARF are also calculated through different types of 
aerosols, chemical uniqueness, and size distribution. Therefore, an accurate assessment of ARF is a difficult task and remains more uncertain for the climate system (IPCC, 2013; Bibi et al., 2017).

Several studies in the Amazon basin have already addressed the evaluation of the optical and radiative properties of aerosols (Procopio et al., 2003, 2004; Patadia et al., 2008; Rizzo et al., 2011, 2013; Artaxo et al., 2013; Sena et al., 2013; Sena and Artaxo., 2015). These studies were carried out for different periods and used different methodologies to quantify and characterize the disturbances caused by aerosols (Procopio et al., 2004; Patadia et al., 2008; Sena et al., 2013). However, local studies on ARF time series attempt to minimize the uncertainties associated with their estimation. In this study, the aerosol optical and radiative characteristics over the Amazon rainforest were investigated for a seven-year period (2011-2017). The spectral variation of the AOD, SSA, and AP variables measured using AErosol ROboticNETwork (AERONET) data was analyzed. Thereafter, the difference between SSA data retrieved from AERONET and SSA calculated using measurements on the ground surface was shown. AERONET radiative forcing products were also used. Monthly, seasonal, and annual variations of the shortwave aerosol radiative forcing (SWARF) on top of atmosphere (TOA), surface (SUR), and within the atmosphere (ATM), along with atmospheric heating rate (HR) were calculated using the Santa Barbara DISORT Atmospheric Radiative Transfer (SBDART) model. A regression analysis of the AERONET-SBDART forcing was also performed to validate the measurements simulated by the SBDART.

\section{Site description, measurement, and methods}

\subsection{Site, instrumentation, and data}

This study was carried out with measurements at two sites of the GoAmazon 2014/5 experiment (Martin et al., 2016). The characterization of the optical properties of the aerosols used as input to the radiative transfer code was carried out based on AERONET measurements at site T0e or EMBRAPA (Empresa Brasileira de Pesquisas Agropecuárias; $2.8942^{\circ} \mathrm{S}$, $59.9718^{\circ} \mathrm{W}$ ) (Barbosa et al., 2014) located $25 \mathrm{~km}$ NNW of Manaus (Fig. 1a), a developing city with a population of 1.8 million people (IBGE, 2015). There is little biomass burning activity in the region, but the site is affected by the regional transport of pollutants from biomass burning, especially in the dry season (Rizzo et al., 2013). The values obtained for the SSA of the atmospheric column at $\mathrm{T} 0 \mathrm{e}$ were related to in situ measurements at site T0a (Amazonian Tall Tower Observatory [ATTO]; $2.1466^{\circ} \mathrm{S}, 59.0050^{\circ} \mathrm{W}$ ) (Andreae et al., 2015), located $150 \mathrm{~km}$ to the northeast of Manaus (Fig. 1a).

In this study, the dry and wet seasons were defined through the time series of AERONET data AOD and through aerosol scattering and absorption coefficients at different wavelengths, according to Rizzo et al. (2013). The dry season was defined from September to December, while the wet season from March to June. This definition may not be strictly correct from a climatological point of view, since the beginning of each season changes from year to year depending on precipitation patterns; however, considering the purposes of the interpretation of the aerosol dataset, this is a reasonable choice (Rizzo et al., 2013, 2018). In this way, it is possible to evaluate more clearly the impacts caused by aerosols from biomass burning (dry season), as well as the effect of natural biogenic aerosols (wet season). Figure $1 \mathrm{~b}$ shows the micrometeorological characterization of the site T0a, showing the monthly values for precipitation (PRP), air temperature (Tair), relative humidity (RU), and shortwave radiation.

In this paper, the data used were retrieved by CIMEL sun/sky radiometers, which are part of the AERONET global network. Measurements of direct sun radiation were performed in eight $(340-1640 \mathrm{~nm})$ spectral channels with an uncertainty of $\approx 0.01-0.02$ for AOD recoveries (Eck et al., 1999), and the amount of water vapor column was measured at $940 \mathrm{~nm}$ (Holben et al., 2001). In addition, inversion products were recovered in four spectral channels (440, 670, 870, and $1020 \mathrm{~nm}$ ) (Dubovik et al., 2002). Data were available in three levels of quality: level 1.0 contained unpatched data, level 1.5 contained data that tested in the cloud, and level 2.0 data were tracked in the cloud with guaranteed quality (available from the AERONET website at http://aeronet.gsfc.nasa. gov/). Level 2.0 data underwent a final calibration process with information specific to each site, which is detailed by Dubovik et al. (2002). In this study, 2.0 level data of AOD, SSA, and AP were inversion 


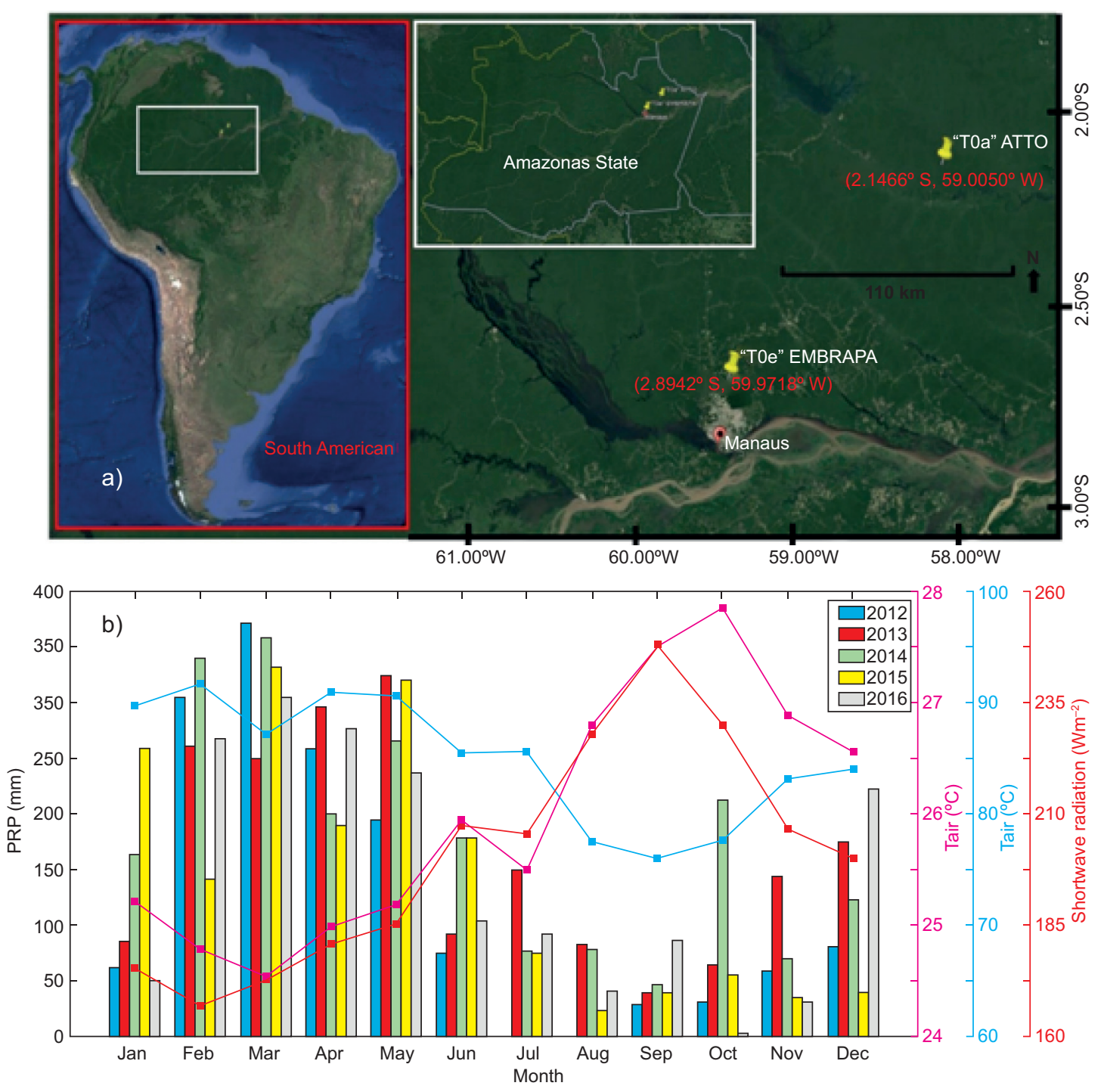

Fig. 1. (a) Location of the study area. The yellow marks are the T0a and T0e sites. The red mark is Manaus in the State of Amazonas, Central Amazon, Brazil. (b) Micrometeorological characterization of T0a, showing the monthly averages of precipitation (PRP), air temperature (Tair), relative humidity (RU), and shortwave radiation.

products retrieved from a selected sunphotometer over T0e (2011-2017). Besides being used for spectral analysis, these data were also used as an input to the SBDART radiative transfer code. Before performing the analysis, AOD values between T0a and T0e (from 2016 to 2017) were compared, assuming that aerosol concentrations were similar for the two sites. Thus, a long time series (T0e) was considered. Direct products were also used, such as AOD $500 \mathrm{~nm}$ total, coarse and fine fractions, precipitable water, and angstrom exponent 440-870 $\mathrm{nm}$.
Surface measurements were performed at site T0a from 2014 to 2017 with a 5-min temporal resolution as well as daily and 15-day averages for the analysis of the time series. All measurements were done under dry conditions (RH 30-40\%), assured by an automatic diffusion dryer (Tuch et al., 2009). Inlet lines ran from the measurement level ( 80 magl, about $51 \mathrm{~m}$ above the canopy height) to an air-conditioned container at ground level. The inlet particle size cutoff was PM 2.5. The aerosol particle scattering coefficients were measured using a three-wavelength 
integrating nephelometer (Aurora Ecotech 3000) operating at 450,525, and $635 \mathrm{~nm}$. Every six months the instrument was calibrated using filtered air and $\mathrm{CO}_{2}$. Sampling time varied between 1 and $5 \mathrm{~min}$. Data were corrected for truncation errors according to Anderson and Ogren (1998) using the tabulated factors for total scatter as a linear function of Angstrom exponent with no cutoff at the inlet (Rizzo et al., 2011, 2013). Aerosol particle absorption was measured using a MAAP photometer (MultiAngle Absorption Photometer, model 5012, Thermo) (Petzold et al., 2005). MAAP reported black carbon (BC) concentrations at $637 \mathrm{~nm}$, which were converted to absorption coefficients assuming a mass absorption coefficient of $6.6 \mathrm{~m}^{2} \mathrm{~g}^{-1}$ used in the firmware of the instrument. Particle absorption coefficients were measured every minute, and a 5\% correction was applied to the data to account for wavelength adjustment (Müller et al., 2011).

\subsection{Data analysis}

The nephelometer scattering measurements (in situ) were interpolated with the wavelength common to MAAP at $637 \mathrm{~nm}$. With the paired measurements of scattering coefficients and absorption coefficients, SSA was calculated at $637 \mathrm{~nm}$ using the following equation.

$S S A(637)=\frac{\sigma_{s}(637)}{\sigma_{s}(637)+\sigma_{a}(637)}$

SSA values as well as the absorption and scattering coefficients were calculated monthly. In addition, SSA data calculated using Eq. 1 were compared with SSA obtained at $675 \mathrm{~nm}$ from the AERONET station.

The AERONET optical parameters (AOD, SSA, and AP) were analyzed for seasonal variations. These optical parameters fed the SBDART radiative transfer code. Simulations with the SBDART returned the radiative fluxes to the SUR and TOA. SBDART outflows (TOA and SUR) were compared to fluxes estimated by the AERONET algorithm. Furthermore, SWARF (TOA and SUR) instantaneous values were validated according to AERONET estimates using the statistical parameters: coefficient of determination $\left(\mathrm{R}^{2}\right.$, Eq. 2$)$, mean absolute error (Eq. 3), root mean square error (Eq. 4) and Willmott's coefficient (Eq. 5):

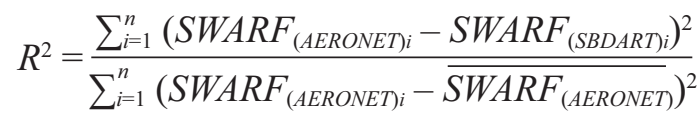

$$
\begin{aligned}
& M A E=\frac{1}{n} \sum_{i=1}^{n}\left(\left|S W A R F_{(S B D A R T) i}-\operatorname{SWARF}_{(\text {AERONET }) i}\right|\right) \\
& R M A E=\sqrt{\frac{1}{n} \sum_{i=1}^{n}\left(\mid S W A R F_{(S B D A R T) i}-S W A R F_{(A E R O N E T) i}\right)}
\end{aligned}
$$

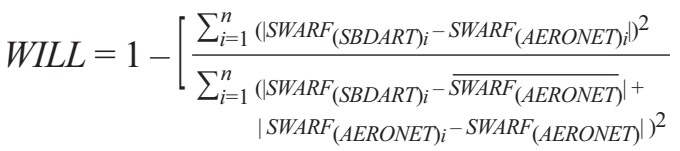

In this study, SWARF was defined as the difference between calculated net fluxes with and without an aerosol load in the atmosphere. The average daily SWARF calculations in TOA and SUR were performed using the SBDART model for the study period. Radiation fluxes were used to obtain

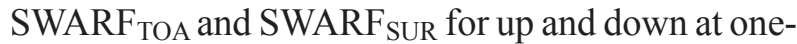
hour intervals for a period of $24 \mathrm{~h}$ with and without aerosol conditions separately. The radiative forcing in the TOA and the surface were obtained as the difference between the downstream and upstream fluxes, with and without aerosols. The averaged SWARF is often expressed as Eq. (6). The fluxes were calculated for the solar spectrum $(0.20-4.00$ $\mu \mathrm{m})$ on a vegetated surface. The solar spectrum was chosen because of later comparisons with the AERONET fluxes that are estimated by the Global Atmospheric Model (GAME) code (Dubuisson et al., 1996; Roger et al., 2006).

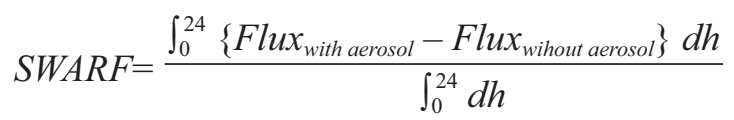

The $\mathrm{SWARF}_{\mathrm{ATM}}$ values were estimated as the difference between the radiative forcing at TOA $\left(\mathrm{SWARF}_{\mathrm{TOA}}\right)$ and SUR $\left(\mathrm{SWARF}_{\mathrm{SUR}}\right)$ using the following equation:

$\triangle S W A R F_{A T M}=S W A R F_{T O A}-S W A R F_{S U R}$

$\mathrm{SWARF}_{\mathrm{ATM}}\left(\right.$ in $\mathrm{W} \mathrm{m}^{-2}$ ) represents the amount of solar radiation trapped in the atmosphere by aerosols. The higher the amount of $\triangle \mathrm{SWARF}_{\mathrm{ATM}}$, the higher the amount of energy retained. In this way, the HR due to the absorption of aerosols is calculated from the first law of thermodynamics and hydrostatic equilibrium suggested by Liou (2002):

$\frac{\partial T}{\partial t}=\frac{g}{C_{p} \Delta P} \Delta S W A R F_{A T M}$ 
where $\partial T / \partial t$ is the HR in $\mathrm{K}_{\text {day }}{ }^{-1}, g$ is the gravity acceleration $\left(9.8 \mathrm{~m} \mathrm{~s}^{-2}\right), C p$ is the specific heat capacity of air at constant pressure (i.e., $1006 \mathrm{~J} \mathrm{~kg}^{-1}$ $\mathrm{K}^{-1}$ ) and $P$ is the atmospheric pressure difference between the surface and $3 \mathrm{~km}$, where most of the aerosols are found. Therefore, $P$ was taken as 300 hPa (Kaskaoutis et al., 2013; Singh et al., 2016; Bibi et al., 2017).

\section{Results and discussion}

\subsection{Variability of aerosol optical properties}

The complete time series of AOD $500 \mathrm{~nm}$ is shown in Figure 2a, b, for sites T0a (2016-2017) and T0e (2011-2017). Due to the agreement between AOD measurements at both sites, measurements at $\mathrm{T} 0 \mathrm{e}$ were adopted as representatives of a pristine forest region and were used in the radiative transfer code (SBDART) for simulations of radiative fluxes. Figure $2 b$ shows the seasonality of the optical properties of aerosols in the study area. The rise of aerosol loads during the dry increases AOD values, since fires cause changes in the optical properties and concentrations of aerosols in the Amazon basin (Sena et al., 2013; Artaxo et al., 2013; Rizzo et al., 2013).
Figure $2 \mathrm{~b}$ also shows year-to-year variations in the optical properties of aerosol particles occurring mainly due to variations in the amount of precipitation and biomass burning sources (Rizzo et al., 2013). The maximum AOD (1.8) was observed in 2015. However, no maximum AOD reached values higher than 1.0 for other years. This trend was due to an increase in the number of fires during the same period, which was approximately 26\% (from 84 to 115 fires) in the period 2014-2015.

Aerosol parameters obtained from the AERONET station depend on the number of fires in the Amazon forest, which release large amounts of particles and gases into the atmosphere influencing the chemical composition and optical properties of aerosols, which directly affect the forcing of radiative fluxes. To complement the analysis of variations in the optical properties of aerosols, Figure 3 shows the average 15 days of AERONET parameters and in situ measurements, as well as the monthly distribution of fires over the Legal Amazon (which is the territorial extension covering the Brazilian states that contain the Amazon biome) and the states of Amazonas and Pará.

Additionally, the seasonal variation observed for the optical properties of aerosols in the atmospheric
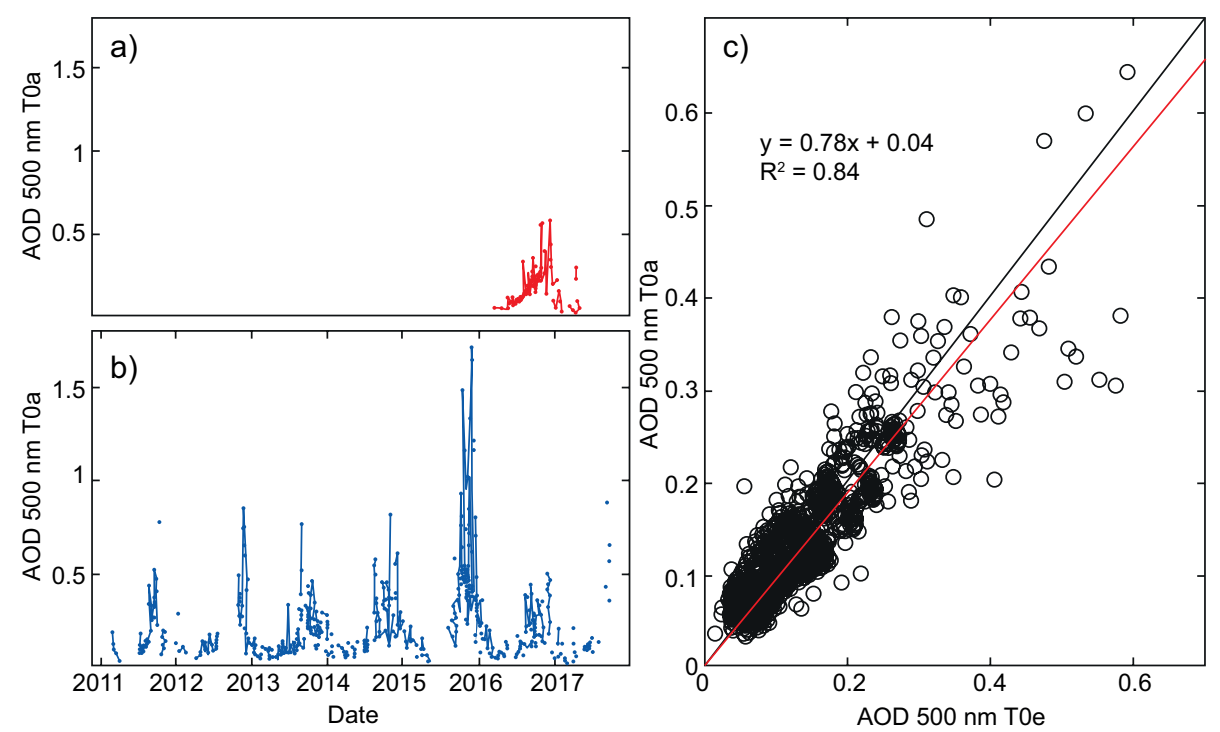

Fig. 2. (a) Time series of aerosol optical depth (AOD, $500 \mathrm{~nm}$ ) retrieved by AERONET sun-photometer in Central Amazonia for T0a (ATTO) and (b) T0e (EMBRAPA); (c) linear regression for AOD $(500 \mathrm{~nm})$ at T0e and AOD $(500 \mathrm{~nm})$ instantaneous measurements at T0a. 


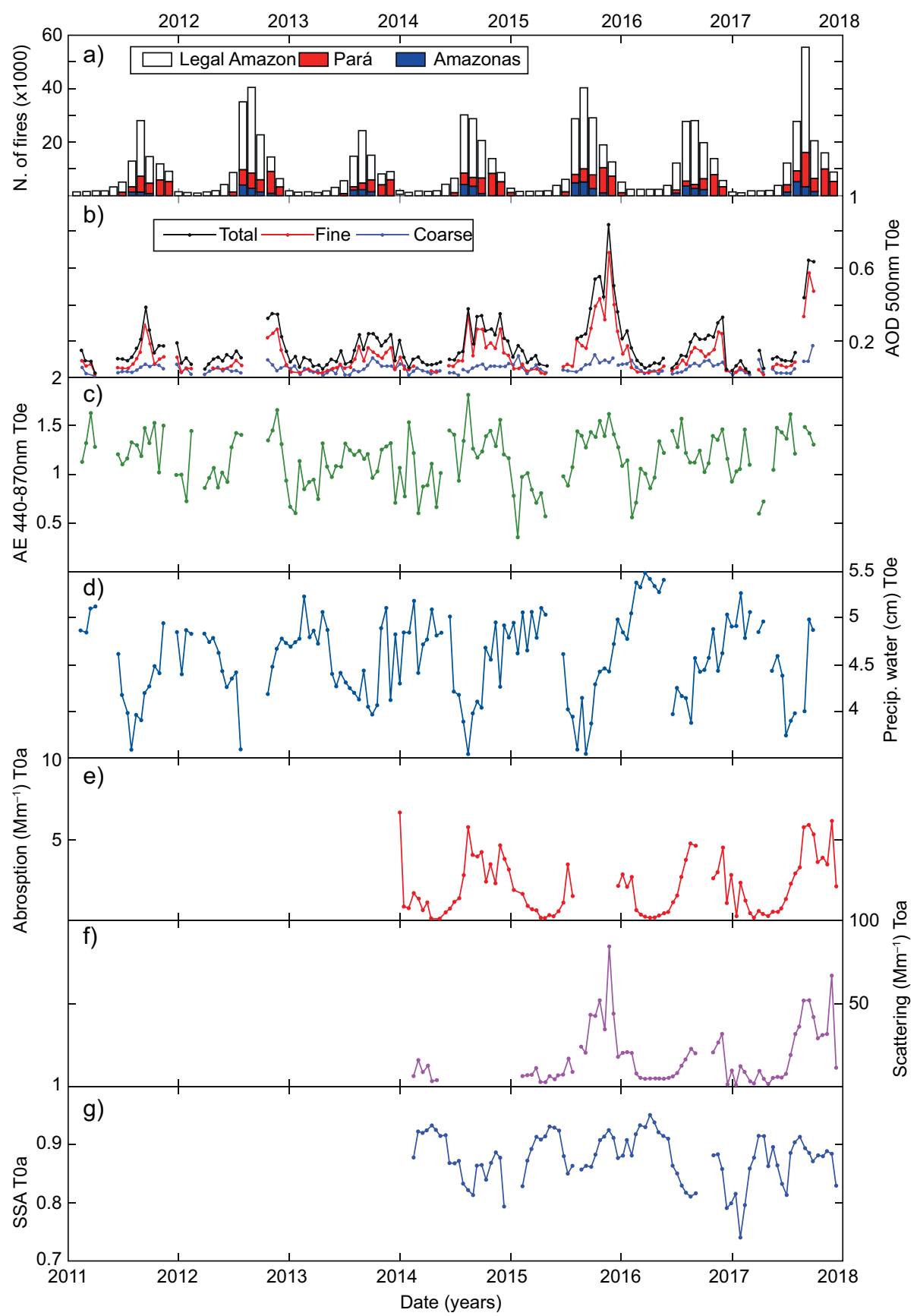

Fig. 3. (a) Monthly distribution of fires over the legal Amazon and the states of Amazonas and Pará; reference satellite: Aqua MODIS afternoon (Instituto Nacional de Pesquisas Espaciais). (b) Total AOD (500 nm) and coarse and fine fractions at T0e. (c) Angstrom exponent (440-870 nm) at T0e. (d) Precipitable water at T0e. (e) Absorption coefficient $(637 \mathrm{~nm})$ at T0a. (f) Scattering coefficient $(637 \mathrm{~nm})$ at T0a. (g) SSA (637 nm) at T0a.

column can also be seen on the surface. Figure 3 shows that the particle scattering coefficients increased substantially under the influence of biomass burning particles. This is a consequence of the increased fine-particle concentration in the dry season, which is more efficient at scattering light compared to 
the coarse mode dominated biogenic particles in the wet season (Fig. 3b). There is an observed difference between the scattering coefficient values for the years 2014 and 2015 in Figure 3. The scattering coefficients reached maximum values between 160 and 180 $\mathrm{Mm}^{-1}$ in 2014, while the maximum value in 2015 was $600 \mathrm{Mm}^{-1}$. The increase in scattering coefficient values from 2014 to 2015 was already expected due to the substantial increase in the records of biomass burning occurred in the Amazon basin during the same period. Although there were no fire outbreaks at the forest site, it was influenced by regional emissions of biomass burning carried by air masses (Rizzo et al., 2011, 2013).

Deforestation fires can smolder for days, producing particles at high emission factor rates with small black carbon content, thereby decreasing the aerosol absorption and increasing the aerosol scattering of the original plume (Reid et al., 2005). Evidence shows an increased tendency in the scattering of light by aged particles due to physical and chemical atmospheric processes which act in the increase of particle sizes (Brito et al., 2014). Conversely, in situ observations of biomass burning indicate that concentrations of carbonaceous aerosols normally decrease by 10 to $50 \%$ local (fresh) emissions compared to regional emissions. (Capes et al., 2008), through dilution with cleaner background air. In this way, it is reasonable that the dispersion of particles and absorption coefficients vary by different factors, depending on the plume characteristics and atmospheric conditions (Rizzo et al., 2013).

The barplots for scattering coefficients , absorption coefficients, and SSA with the wavelength of $637 \mathrm{~nm}$ for the years 2014 and 2017 are presented in Figure 4. We observed a 10-fold increase in from May to October (from 4 to $40 \mathrm{Mm}^{-1}$ ). The variation in the absorption by aerosols was 1 to $3 \mathrm{Mm}^{-1}$ for May and August, respectively. These results are in accordance with those of Artaxo et al. (2013) for a nearby area, which is also a pristine forest (TT34; Artaxo et al., 2013). There is little burning activity during the wet season, and the absorption coefficients observed at the time are attributed to biogenic particles (Pöschl et al., 2010; Rizzo et al., 2013). In the wet season SSA reached maximum average values

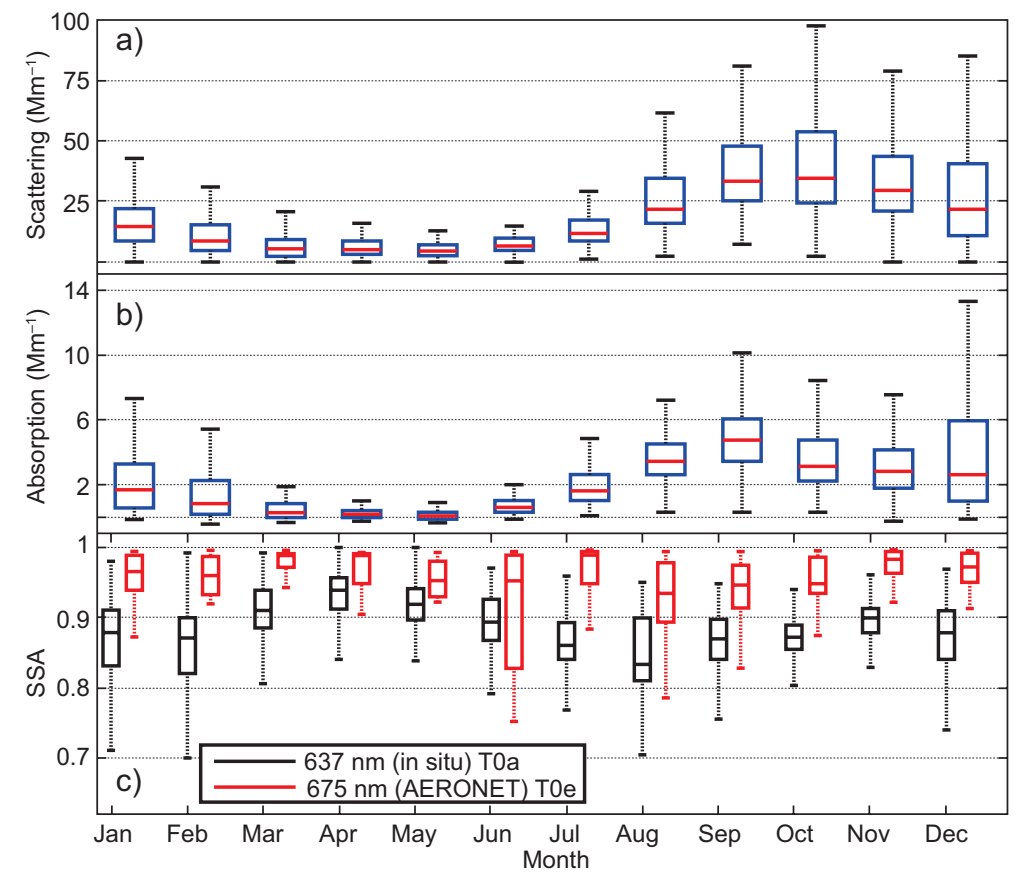

Fig. 4. (a) Boxplot for light scattering coeffcient at $637 \mathrm{~nm}$ in T0a from 2014 to 2017, (b) light absorption coeffcient at $637 \mathrm{~nm}$ in T0a from 2014 to 2017 , and (c) single scattering albedo (SSA) at $637 \mathrm{~nm}$ in T0a (black) and T0e (red) from 2014 to 2017. 
of 0.88 , while average values in the dry season were 0.86. Although the magnitudes of dry and wet seasons averages are close, it is possible to observe that the month-to-month variation is much more evident, ranging from 0.92 in May to 0.83 in August.

Rizzo et al. (2013) also analyzed the seasonal pattern of SSA in a forest located in the central region of the Amazon, finding no difference between medians in the dry and wet seasons. Furthermore, Rizzo et al. (2013) results (SSA $=0.88$ for both seasons) resemble the results obtained in this study $(\mathrm{SSA}=0.88$ in the wet season and $\mathrm{SSA}=0.86$ in the dry season). The low $\mathrm{SSA}$ values $(\mathrm{SSA}=0.83)$ found in the wet season are due to low scattering values (driven by low aerosol loads) combined with the absorption coefficients driven by the presence of light-absorbing biogenic aerosols (Artaxo et al., 2013).

The monthly variation of SSA values (Fig. 4) was due to microclimatic conditions (Fig. 1b), transport, and local contributions of biomass burning. Moreover, the high SSA variability found in February may be associated with the influence of mineral dust and aged particles from biomass burning from the advection of aerosols from Africa. This contribution affects the absorption coefficients, while the scattering coefficients are not significantly affected (Rizzo et al., 2013). In addition, the highest SSA medians were found in April and May due to the organic fraction, which can spread the radiation efficiently. Besides, the high atmospheric moisture content causes an increase in the submicron particles diameters, which consequently cause an increase in the scattering and then in the values of SSA (Fig. 3d). The SSA decreased approximately 10\% from May to August, which is due to biomass burning in the neighboring regions and the high absorption power of black carbon. There was a slight increase in SSA from August to December due to blending processes between the burning plumes that reached the study area and local particles. This causes an increase in the scattering of light caused by organic aerosols from biomass burning.

The seasonal pattern of SSA calculated in situ was consistent with AERONET measurements in the atmospheric column (Fig. 4c). According to Anderson et al. (1999), the values of SSA in natural conditions of high humidity for the atmospheric column should be higher than the dry measurements taken on sur- face. In this study, an average difference of $8.4 \pm$ $2.9 \%$ was obtained between SSA calculated in situ and AERONET measurements in the atmospheric column. There was no significant difference between in situ and the atmospheric column, however, there is an observed strong month-to-month difference.

Besides, the lowest difference obtained between SSA calculated in situ and AERONET measurements was found in May (3.0\%). The maximum difference was $11.8 \%$ in August and September. Although the monthly pattern for both measurements was similar, the atmospheric water content increased considerably the SSA. Likewise, SSA medians in the wet season were observed as high as 0.99 in the atmospheric column, which highlights the dominant effect of scattering on the radiation extinction.

\subsection{Influence of fire activities}

For illustration purposes, Figure 5 shows the 24-h compilation of fire outbreaks (INPE, 2018) with the HYSPLIT trajectory model for October 4, 2015. This illustration supports the hypothesis that the major contribution of biomass burning emissions comes from neighboring regions. The outbreaks of fires in the state of Pará (Fig. 3a) directly influence the study area. The work of Palácios et al. (2020) about the study area points out that during the change from wet to dry season, the fraction of biogenic aerosols practically does not change, however the mixtures OC-EC, characteristics of biomass burning, go from $16 \%$ to $28 \%$ from wet to dry season.

In general, the results presented in Figures 3 and 4 reflect the complex mixture of aerosol during the period of biomass burning in the region, between August and October. During this period, local and regional influences produce fresh (less-oxidized) organic aerosols from biomass burning (BBOA) which mix with quite-aged (more-oxidized) aerosols from Africa. This complex mixture strongly modulates optical properties in the Amazon throughout the year (Saturno et al., 2018; de Sá et al., 2019). External factors, such as El Niño 2015, and the increase in the number of regional fires, also contributed strongly to the significant increase in the scattering coefficient (4-40 $\mathrm{Mm}^{-1}$ ), absorption values (1-3 $\left.\mathrm{Mm}^{-1}\right)$, and the lowest SSA values (0.92-0.83) observed that year. These results are, respectively, in ascending order, from $24 \pm 18$ to $48 \pm 33 \mathrm{Mm}^{-1}$ and from 3.8 


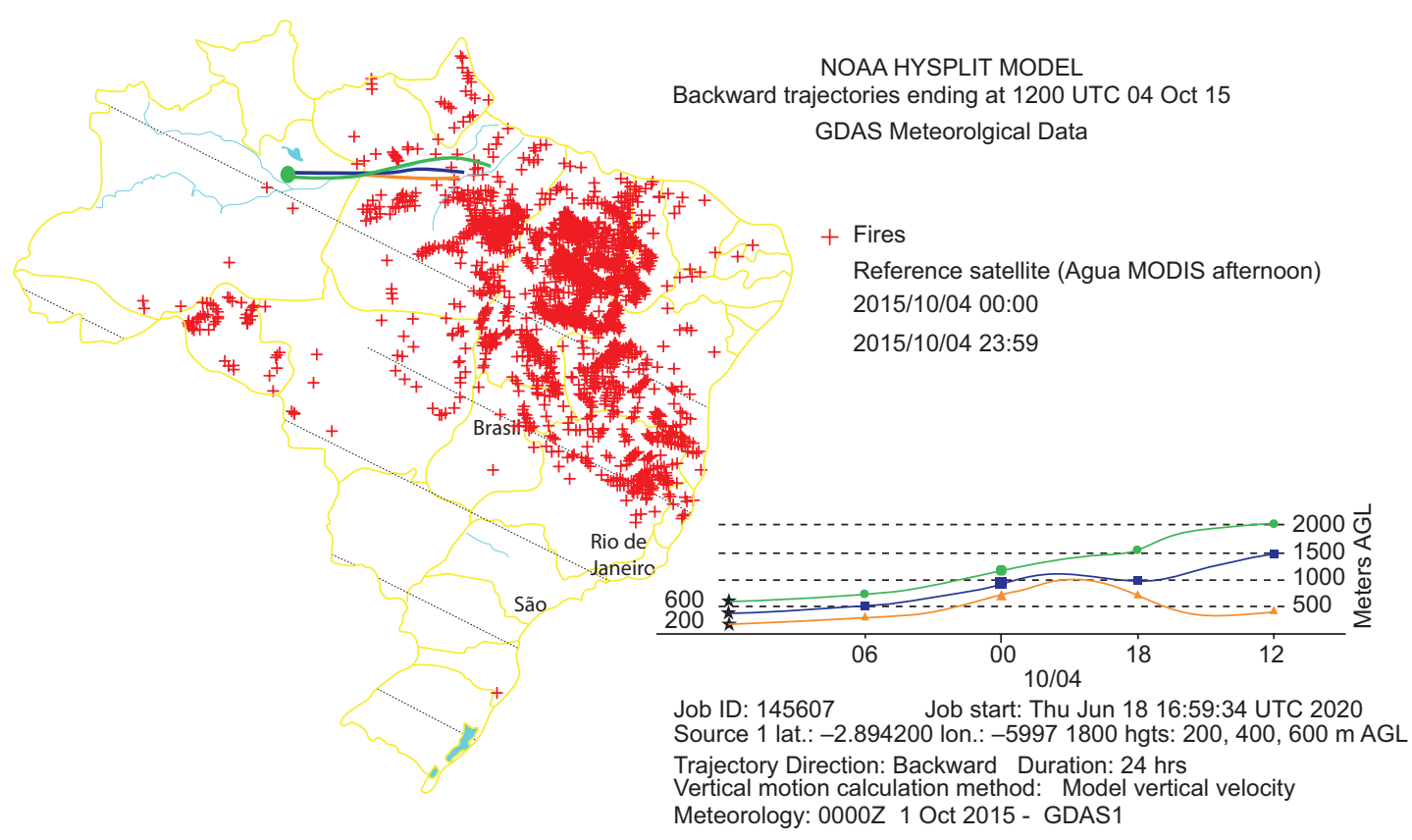

Fig. 5. 24-h compilation of fire spots. Aqua MODIS afternoon (INPE) reference satellite with the HYSPLIT trajectory model (backward trajectories) for October 4, 2015.

\pm 2.8 to $5.3 \pm 2.5 \mathrm{Mm}^{-1}$, and in the descending order of 0.96-0.86 presented by Saturno et al. (2018) using data from ATTO and ZF2 (Manaus-AM). During most part of the period September-October these variations are intrinsically linked to the $27-47 \%$ increase in $\mathrm{BrC}$ concentration due to regional fires in South America, although Africa's BBOA is the main source of pollution at ATTO during August (Saturno et al., 2018).

Several other mechanisms have also been suggested to explain the changes observed in optical properties, many of them as a function of the chemical composition of aerosol (not evaluated in this study). For example, the dominant presence of primary organic aerosol (POA) and long-range transport (LRT) of dust from North Africa (Saleh et al., 2103; Pokhrel et al., 2016) may explain the low absorption values observed during the wet season (Figs. 3-4). The presence of POA seems to be more associated with high BC-to- organic aerosol (OA) values which are more efficient absorbers of solar radiation in relation to secondary organic aerosol (SOA) (Saleh et al., 2014; de Sá et al., 2019).

A statistically significant relationship between absorption coefficients, $\mathrm{BrC}$, and particulate matter
(PM), along with the organic PM chemical composition was also found in the Amazon (Brito et al., 2014). Recent studies have shown that light absorption by BrC decreases not only with LRT (Lin et al., 2016) but also due to rises in the O:C ratio (de Sá et al., 2019). In addition, decreases in the concentration of chemical species associated with nitrogen are more strongly linked to the increase in light absorption. For instance, the percentage contributed by the CxHyOzNC family seems to be higher if compared to the HOA and LO-BBOA, which are generally associated to important sources of $\mathrm{BrC}$ coming from fresh plumes of urban and BB aerosols (Laskin et al., 2015; de Sá et al., 2019). Compounds containing nitrogen and organic molecules, humic-like substances, nitro-aromatic catechols, and aromatic carboxylic acids are among the main solar radiation absorbing constituents during the biomass burning season in the Amazon (Claeys et al., 2012; Lin et al., 2016; de Sá et al., 2019). This evidence corroborates the highest absorption values observed in Figs. 3-4, whereas changes in the spreading coefficient are strongly correlated to the oxidation of OA loads during regional transport, and of LRT events from Southern Africa 
(Brito et al., 2014; Saturno et al., 2018). These patterns are inextricably linked to complex atmospheric processing, photolysis by solar radiation, gas-particle reactions, and reactions at the aerosol-cloud interface in the aqueous phase (Saleh et al., 2014; Laskin et al., 2015; de Sá et al., 2019). New studies, however, are still needed to understand the concomitant changes in optical and chemical properties as a function of different types of biomass burning in the Amazon.

\subsection{Spectral variation of $A O D, S S A$, and AP in the atmospheric column}

The SWARF estimates require information on the optical properties of aerosols, AOD, SSA, and AP, as well as the variability of their properties along with the spectral range. Particularly, AOD represents the total extinction of radiation integrated into the atmospheric column, while SSA is the ratio between scattered and absorbed radiation fractions and AP provides information on scattered radiation. These properties are important for the estimation of the radiative forcing of aerosols and different spectral variations revealing the size of the particles.

The AOD median values, SSA and AP obtained in $440,675,870$, and $1020 \mathrm{~nm}$ were plotted for the dry and wet season from 2011 to 2017 (Fig. 6). Additionally, the spectral variation of AOD is adequate to provide details on particle size distribution, which was also verified using the Angstrom exponent (AE) shown in Figure 2 (Eck et al., 2010). AOD was strongly dependent on the wavelength during the dry season, decreasing with the wavelength due to the presence of fine particles, whose result was already expected as a consequence of emissions by biomass burning (Sena et al., 2013; Artaxo et al., 2013). However, the spectral pattern of AOD was not significant in the wet season, presenting a change in aerosol size distribution towards the larger size range, such as coarse particles (Rizzo et al., 2013; Artaxo et al., 2013).

In addition, AOD, SSA, and AP had a smaller spectral dependency in the wet season compared

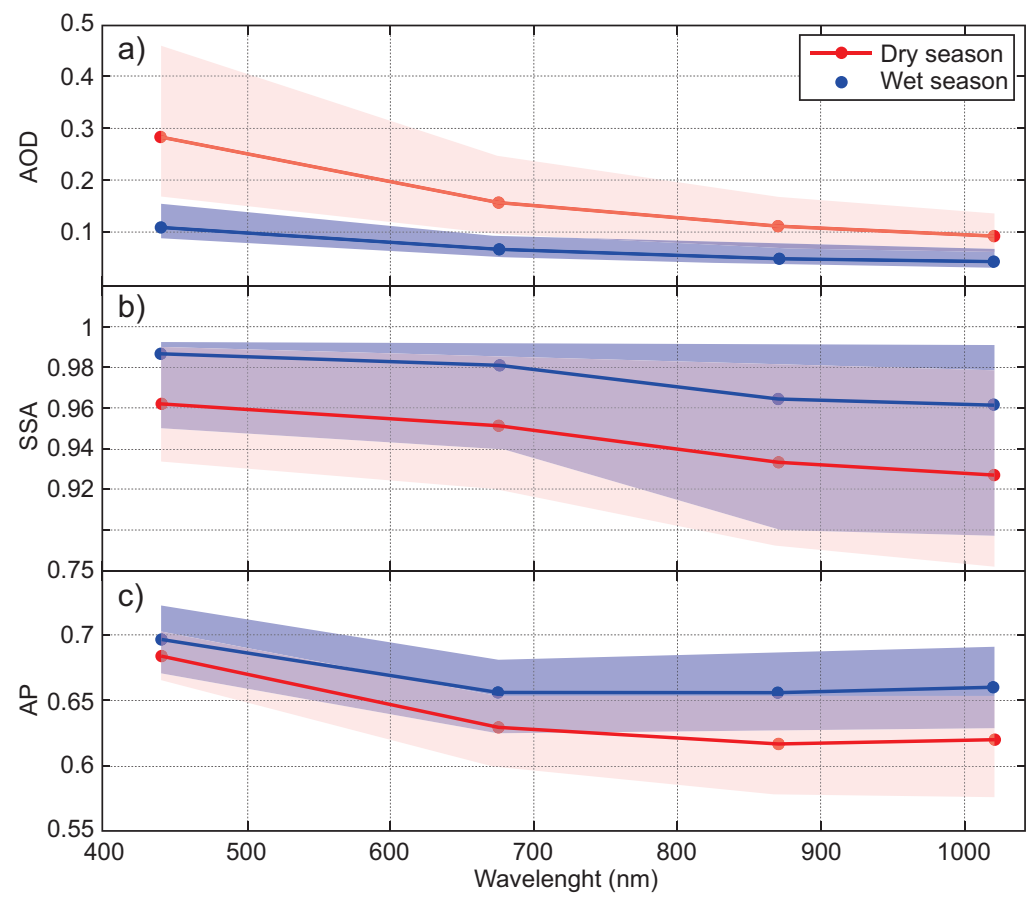

Fig. 6. Spectral variation of (a) aerosol optical depth (AOD), (b) single scattering albedo (SSA), and (c) asymmetry parameter (AP) in the dry (red) and wet (blue) seasons in Central Amazonia (T0e) from 2011 to 2017. The lines represent the medians and intervals are the 25 and 75 percentiles. 
to the dry season (Fig. 6). Low AOD means a low concentration of particles in the atmosphere (Artaxo et al., 2013). There was a small difference in SSA values between dry and wet seasons. Although this difference was not significant, the decrease of SSA in the dry season occurred due to the presence of absorber aerosols emitted by biomass burning in this period (Rizzo et al., 2011, 2013; Sena et al., 2013).

The decrease of AOD and SSA with the wavelength in the dry season occurred in different ways. AOD depends directly on the concentration of optically active particles in the atmospheric column (extensive property) while SSA does not depend on the concentration (intensive), but on the absorption and scattering properties of aerosol. The higher AOD in low wavelengths is due to the increase of fine particles concentrations in this period. However, biomass burning aerosols are more absorbent in the wet season than natural aerosols. Unlike other regions impacted by high aerosol loads (Kaskaoutis et al., 2012; Singh et al., 2016; Bibi et al., 2017), SSA decays with the wavelength because, although the predominance of aerosols is concentrated in coarse particles of aerosols in the wet season, they interact less efficiently with solar radiation (Rizzo et al., 2011).
3.4 Comparison of SWARF (AERONET vS. SBDART)

The direct mean radiative forcing of aerosols (SWARF) was evaluated in a pristine forest within the Amazon basin. The seasonal and interannual variability of SWARF (estimated with the SBDART model with aerosol optical parameters provided by AERONET) was evaluated. Regressions performed for the instantaneous values of SWARF SUR $_{\text {and }}$ SWARF $_{\text {TOA }}$ and the statistical evaluation parameters are shown in Figure 7 and Table I, respectively. There were instantaneous values below $-150 \mathrm{~W}$ $\mathrm{m}^{-2}$ for $\mathrm{SWARF}_{\mathrm{SUR}}$ and $-70 \mathrm{~W} \mathrm{~m}^{-2}$ for $\mathrm{SWARF}_{\mathrm{TOA}}$. Regressions were also made for SWARF (TOA and SUR) values, separating the dry and wet seasons. Regression parameters are also shown in Table I. The error was slightly higher for the regressions in the dry season. However, in general, the associated errors were relatively lower, and the SWARF estimates had good agreement with the AERONET values.

For other locations around the globe, recent studies have shown a good correlation between SWARF values comparing AERONET against SBDART. Adesina et al. (2015) found a high correlation in
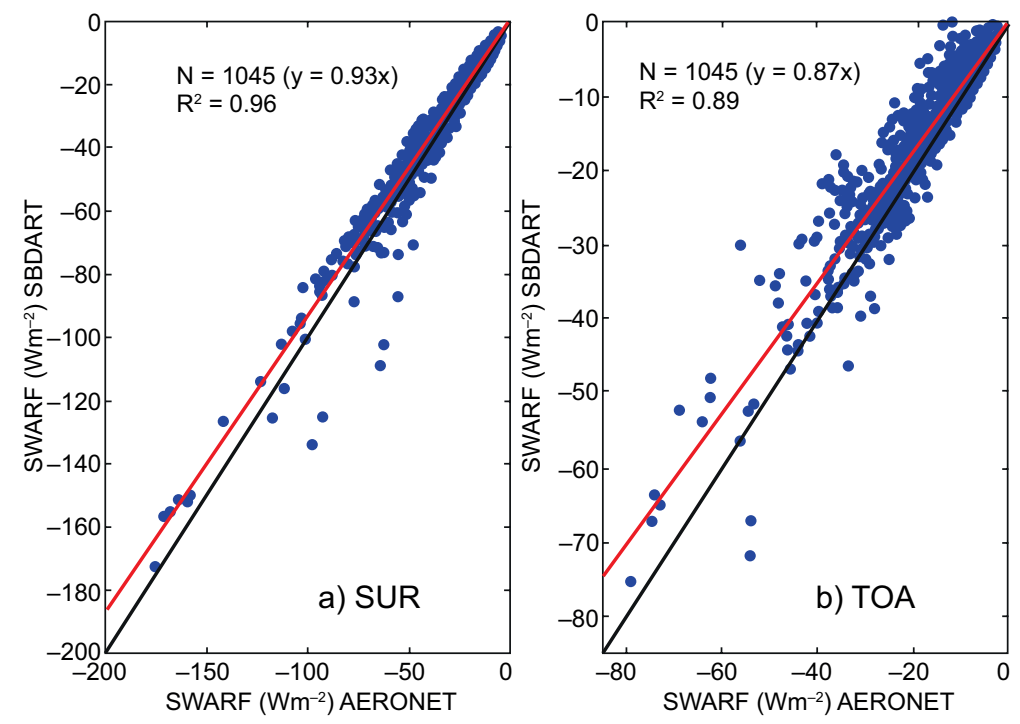

Fig. 7. Scatter plots of AERONET vs. SBDART shortwave aerosol radiative forcing (SWARF) at (a) surface (SUR), and (b) top of the atmosphere (TOA) in Central Amazonia (T0e) from 2011 to 2017. These were instantaneous measurements. 
Table I. Coefficient of determination, errors (MAE and RMSE), and Willmot coefficient between SWARF AERONET vs. SWARF SBDART. Comparisons were performed for SUR and TOA in Central Amazonia (T0e) from 2011 to 2017.

\begin{tabular}{|c|c|c|c|c|c|c|c|c|c|}
\hline & \multirow{2}{*}{$\mathrm{N}$} & \multicolumn{4}{|c|}{ SUR } & \multicolumn{4}{|c|}{ TOA } \\
\hline & & $\mathrm{R}^{2}$ & MAE & RMSE & WILL & $\mathrm{R}^{2}$ & MAE & RMSE & WILL \\
\hline Wet & 92 & 0.94 & 0.13 & 1.36 & 0.99 & 0.77 & 1.21 & 1.41 & 0.98 \\
\hline Dry & 425 & 0.96 & 4.80 & 6.28 & 0.98 & 0.78 & 3.76 & 1.46 & 0.98 \\
\hline All & 1045 & 0.96 & 3.44 & 4.49 & 0.99 & 0.89 & 2.58 & 3.34 & 0.98 \\
\hline
\end{tabular}

SWARF: shortwave aerosol radiative forcing; SUR: surface; TOA: top of the atmosphere. atmosphere; $\mathrm{N}$ : number of pairs with SWARF AND AERONET measurements.

SWARF $_{\text {SUR }}(0.95)$ and $\mathrm{SWARF}_{\mathrm{TOA}}(0.97)$ in Gorongosa, Africa. Li et al. (2010) performed forcing comparisons in TOA and SUR of AERONET and SBDART and found a high correlation (above 0.92 ) in 25 different stations along China during 2006. Alam et al. (2012) reported high correlations (0.98 and 0.99 ) for the SBDART and AERONET measurements for the Karachi and Lahore sites in Pakistan, from 2010 to 2011. Kumar et al. (2015) reported a high correlation ( 0.89 for SUR and 0.78 for TOA) between AERONET and SBDART during the monsoon and pre-monsoon in Kanpur, India. Similarly, Valenzuela et al. (2012), and recently Bibi et al. (2017), found moderate correlations (from 0.5 to 0.8 ) for SUR and TOA in the Indo-Gangetic plains in India.

\subsection{Seasonal and interannual SWARF $24 \mathrm{~h}$}

Atmospheric aerosols are mainly a combination of types of scattering and absorption particles, and their impacts in the form of cooling and heating of the atmosphere are a function of different optical properties (Bibi et al., 2017). In this study, SWARF was calculated separately for TOA and SUR using the SBDART model. However, the difference between $\mathrm{SWARF}_{\mathrm{TOA}}$ and $\mathrm{SWARF}_{\text {SUR }}$ produces $\mathrm{SWARF}_{\mathrm{ATM}}$, which represents the amount of energy retained in the atmosphere by the absorption brought about by aerosols and transformed into thermal energy.

The simulation of SBDART involved the optical properties of aerosols with a 1-h time resolution (2011-2017). The SWARF TOA/SUR $_{\text {time values were }}$ integrated according to Eq. (5) resulting in 24-h $\mathrm{SWARF}_{\text {TOA/SUR. The monthly averages for } 24-\mathrm{h}}$ $\mathrm{SWARF}_{\mathrm{TOA} / \mathrm{SUR} / \mathrm{ATM}}$ are shown in Figure 8. It was observed that monthly averages of $24-\mathrm{h} \mathrm{SWARF}_{\mathrm{TOA}}$ reached -14 and $-36 \mathrm{~W} \mathrm{~m}^{-2}$ for $24-\mathrm{h} \mathrm{SWARF} \mathrm{FUR}_{\text {SUR }}$. However, daily values of 24-h SWARF $\mathrm{SOA}_{\mathrm{TOA}}$ and SWARF $_{\text {SUR }}$ reached values below -30 and $-60 \mathrm{~W} \mathrm{~m}^{-2}$, respectively, in October 2015.

Seasonal and annual means for $\mathrm{SWARF}_{\mathrm{TOA}}$ SUR/ATM are shown in Table II. Its aerosol impact on SWARF significantly increases in the dry season (Fig. 8). Table II shows the average for the whole period. It also shows that 24-h SWARF ${ }_{\mathrm{TOA}}$ practically increases in three times, from -3.66 to $-9.18 \mathrm{~W} \mathrm{~m}^{-2}$ from the wet to dry season. This impact is also felt on the surface, but not in the same proportion: 24-h SWARF ${ }_{\text {SUR }}$ increased from $-11.86 \mathrm{~W} \mathrm{~m}^{-2}$ in the wet season to $-20.77 \mathrm{~W} \mathrm{~m}^{-2}$ in the dry season. The variation between years is also shown in Table II. As seen in Figs. 3-4, it was expected that the greatest impacts on radiative fluxes would occur in the years when the extension of the dry season and the largest load of burnt aerosols reached the study area. There were more than 11000 fire spots in 2015, which is the largest record since 2009. More than 5000 fires were recorded in the state of Amazonas only in September 2015, which is $90.3 \%$ higher than fires registered during the same period in 2014 (INPE, 2018). As seen in Figure 8 and Table II, 24-h SWARF TOA $_{\text {Was }}-14.06 \mathrm{~W} \mathrm{~m}^{-2}$ during the dry season of 2015, which is approximately five times higher than the value found during the wet season $\left(-3.95 \mathrm{~W} \mathrm{~m}^{-2}\right)$. The consequence of $24-\mathrm{h} \mathrm{SWARF} \mathrm{TOA}_{\mathrm{TO}}$ and $\mathrm{SWARF}_{\mathrm{SUR}}$ values is the increase of HR in the atmosphere, which is also shown in Table II.

Comparing our results with other studies, Procopio et al. (2004), Patadia et al. (2008), and Sena et al. (2013) had a spatial approach and were restricted to a specific period of biomass burning aerosols, 


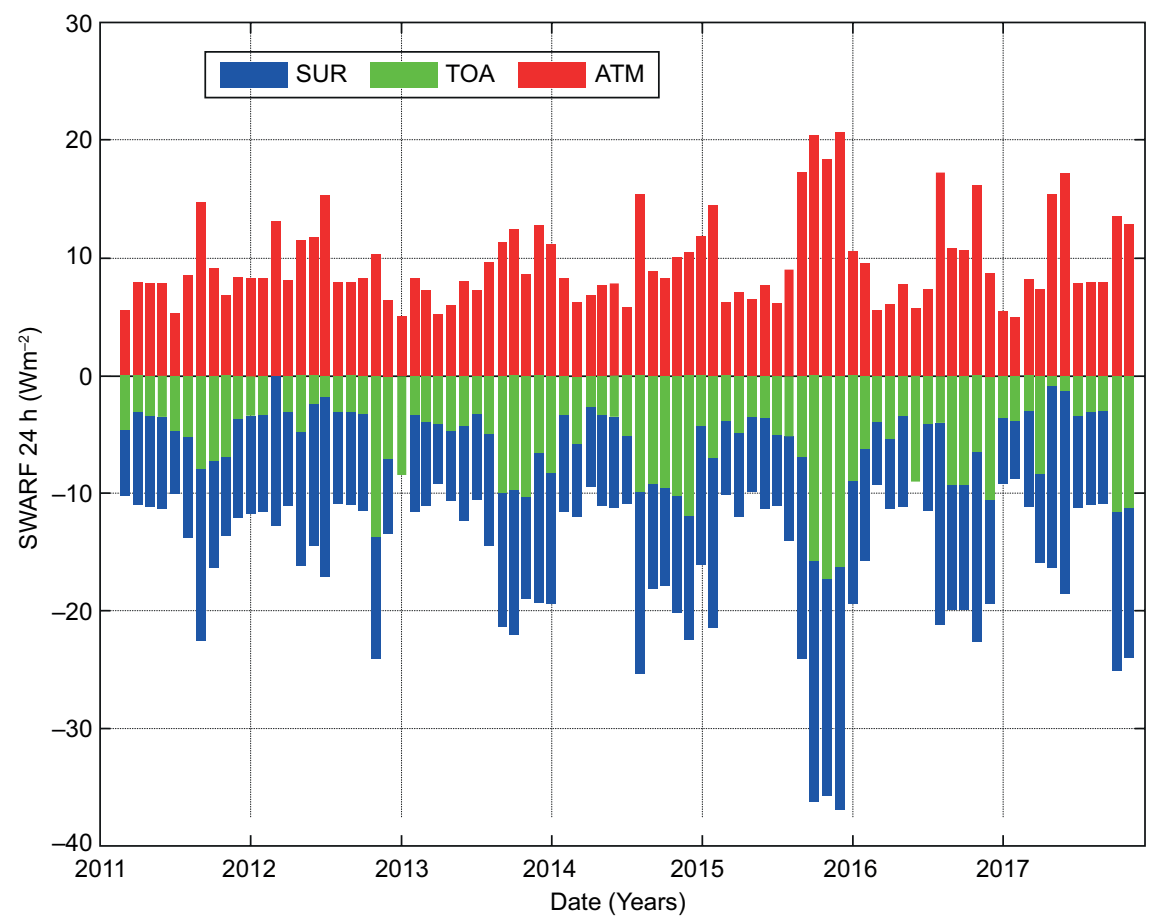

Fig. 8. Monthly variation of 24-h shortwave aerosol radiative forcing (SWARF) at top of the atmosphere (TOA, green), surface (SUR, blue), and within the atmosphere (ATM, red) in Central Amazonia (T0e) from 2011 to 2017.

Table II. Seasonal and interannual mean variations of 24-h SWARF at TOA, SUR, and ATM, and $\mathrm{HR} \pm$ standard deviations in Central Amazonia (T0e) from 2011 to 2017.

\begin{tabular}{lccccc}
\hline & & \multicolumn{3}{c}{$24-\mathrm{h} \mathrm{SWARF}\left(\mathrm{W} \mathrm{m}^{-2}\right)$} & HR \\
\cline { 3 - 4 } & & TOA & SUR & ATM & $\left(\mathrm{K} \mathrm{day}^{-1}\right)$ \\
\hline 2011 & Wet & $-3.7 \pm 0.7$ & $-10.9 \pm 0.5$ & $7.3 \pm 1.2$ & $0.23 \pm 0.33$ \\
& Dry & $-6.4 \pm 1.8$ & $-16.2 \pm 4.5$ & $9.7 \pm 3.5$ & $0.31 \pm 0.11$ \\
\hline 2012 & Wet & $-2.5 \pm 0.8$ & $-13.6 \pm 2.2$ & $8.3 \pm 1.6$ & $0.26 \pm 0.05$ \\
& Dry & $-6.8 \pm 1.5$ & $-15.0 \pm 4.1$ & $11.1 \pm 2.2$ & $0.36 \pm 0.07$ \\
\hline 2013 & Wet & $-4.2 \pm 0.3$ & $-10.9 \pm 1.3$ & $6.6 \pm 1.3$ & $0.21 \pm 0.04$ \\
& Dry & $-9.1 \pm 1.7$ & $-20.4 \pm 1.5$ & $11.3 \pm 1.8$ & $0.36 \pm 0.06$ \\
\hline 2014 & Wet & $-3.8 \pm 1.3$ & $-11.0 \pm 1.1$ & $7.2 \pm 0.8$ & $0.23 \pm 0.02$ \\
& Dry & $-10.2 \pm 1.2$ & $-19.7 \pm 2.1$ & $9.5 \pm 1.0$ & $0.30 \pm 0.03$ \\
\hline 2015 & Wet & $-3.9 \pm 0.1$ & $-10.8 \pm 1.0$ & $6.9 \pm 0.7$ & $0.22 \pm 0.02$ \\
& Dry & $-14.0 \pm 4.8$ & $-33.3 \pm 6.1$ & $19.2 \pm 1.7$ & $0.62 \pm 0.05$ \\
\hline 2016 & Wet & $-3.9 \pm 0.9$ & $-10.2 \pm 1.2$ & $6.2 \pm 1.0$ & $0.20 \pm 0.03$ \\
& Dry & $-8.8 \pm 1.7$ & $-20.5 \pm 1.5$ & $11.6 \pm 3.2$ & $0.36 \pm 0.10$ \\
\hline 2017 & Wet & $-3.4 \pm 0.3$ & $-15.5 \pm 3.0$ & $11.5 \pm 3.0$ & $0.37 \pm 0.09$ \\
& Dry & $-8.6 \pm 1.5$ & $-20.0 \pm 4.8$ & $12.0 \pm 4.9$ & $0.39 \pm 0.16$ \\
\hline All & Wet & $-3.6 \pm 1.6$ & $-11.8 \pm 2.3$ & $8.2 \pm 2.9$ & $0.26 \pm 0.08$ \\
periods & Dry & $-9.1 \pm 2.80$ & $-20.7 \pm 5.0$ & $11.6 \pm 4.04$ & $0.37 \pm 0.13$ \\
\hline
\end{tabular}

SWARF: shortwave aerosol radiative forcing; TOA: top of the atmosphere; SUR: surface; ATM: atmosphere; HR: heating rate. 
Table III. Comparison of 24-h SWARF $\mathrm{TOA}_{\mathrm{TOA}}$ with previous studies*.

\begin{tabular}{llcc}
\hline Reference & Region & Period & $\begin{array}{c}\text { 24-h SWARF } \\
\left(\mathrm{W} \mathrm{m}^{-2}\right)\end{array}$ \\
\hline Sena et al. (2013) & Amazon & $2000-2009$ & $-5.6 \pm 1.7$ \\
Sena et al. (2013) & Forest & $2000-2009$ & $-6.2 \pm 1.9$ \\
Patadia et al. (2008) & Amazon & $2000-2005$ & $-7.6 \pm 1.9$ \\
Procópio et al. (2004) & AF & $1993-2002$ & $-8.3 \pm 2.0$ \\
Procópio et al. (2004) & AH & $1994-2002$ & $-8.4 \pm 2.2$ \\
This work & Forest & $2011-2017$ & $-5.5 \pm 2.8$ \\
\hline
\end{tabular}

*Results calculated for aerosols from biomass burning.

SWARF: shortwave aerosol radiative forcing; AF: Alta Floresta

AERONET site; AH: Abracos Hill (Ji Paraná) AERONET site.

while this study was punctual and it was carried out both in the dry and wet seasons. Considering that the effect of aerosols from biomass burning is the result of the difference in effects between the dry $\left(-9.1 \mathrm{~W} \mathrm{~m}^{-2}\right)$ and wet $\left(-3.6 \mathrm{~W} \mathrm{~m}^{-2}\right)$ seasons (Table II), this study estimates that $\mathrm{SWARF}_{\mathrm{TOA}}$ caused by biomass burning aerosols is $-5.5 \mathrm{~W} \mathrm{~m}^{-2}$. This value is consistent with Patadia et al. (2008) and Sena et al. (2013). Table III compares the results of this and other studies for $\mathrm{SWARF}_{\mathrm{TOA}}$ values due to the effects of biomass burning aerosols.

The monthly averaged values of SWARF $\mathrm{SOA}_{\text {, }}$ SWARF $_{\text {SUR }}$, and SWARF $_{\text {ATM }}$ were calculated using daily averaged ARF (24-h SWARF) from 2011 to 2017. Monthly averaged SWARF TOA/SUR/ATM values for the entire study period, as well as HR, are shown in Figure 9. Monthly statistics have a good agreement with the seasonal mean values obtained in Table II.
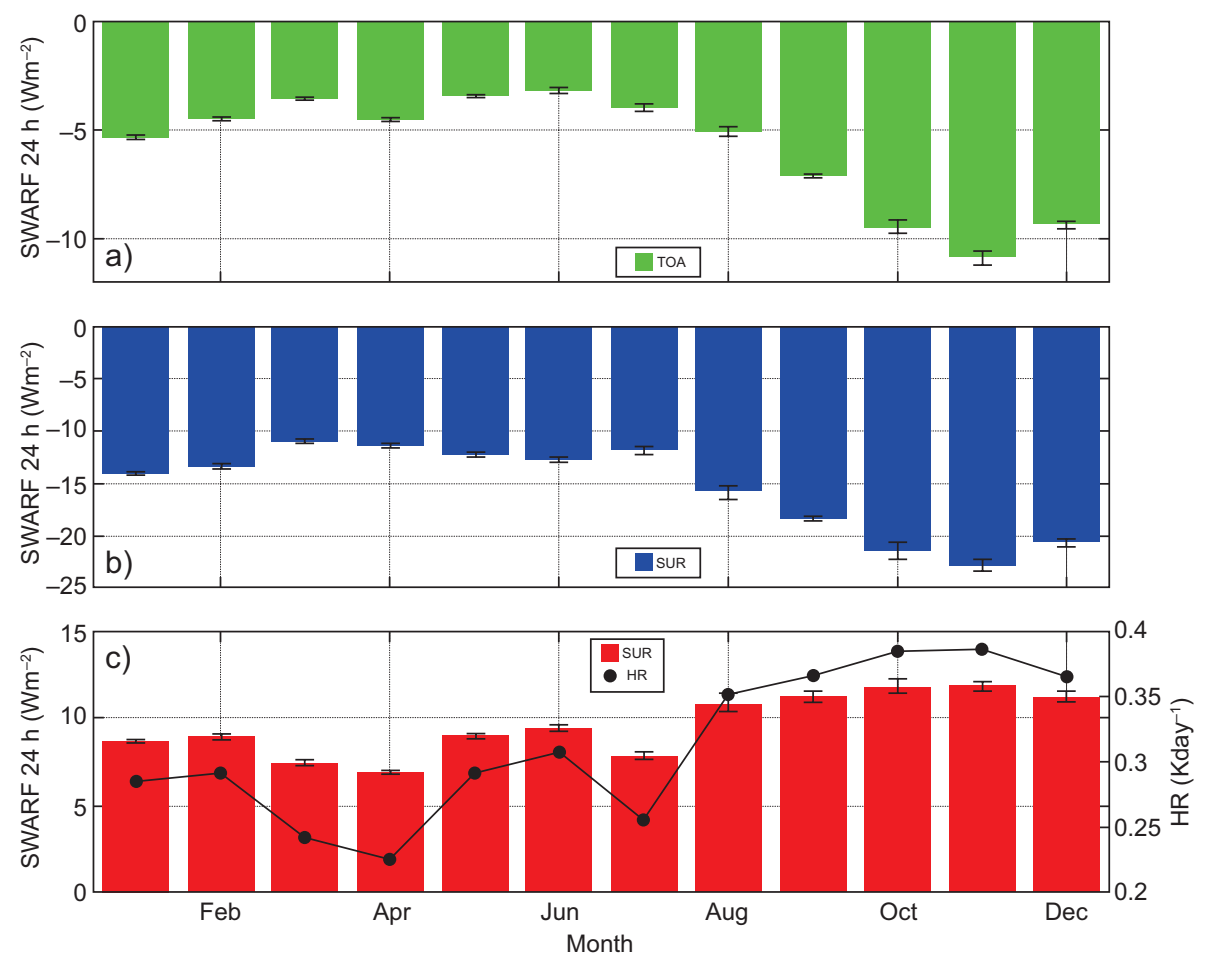

Fig. 9. (a) Monthly averages for 24-h SWARF \pm standard deviations and for TOA (green bar), b) SUR (blue bar), c) ATM (red bar), and HR (black line) in Central Amazonia (T0e) from 2011 to 2017. 
Furthermore, small variations in monthly averages are observed from July to December. Although HR seasonal values hardly vary (Table II), their decrease is clearly observed, with a minimum value in April (Fig. 9c). Variations are evident in the monthly averages. As expected, the HR variation follows the $\mathrm{SWARF}_{\mathrm{ATM}}$ values. Its decrease is clearly observed, with a minimum value in March and April (wet season).

The radiative and consequently the climatic implications of atmospheric aerosols are analyzed in the form of atmospheric HR. As seen in Eq. (7), HR depends directly on the $\mathrm{SWARF}_{\mathrm{ATM}}$ variation, which depends on the SWARF $\mathrm{SOA}_{\mathrm{TO}}$ and $\mathrm{SWARF}_{\mathrm{SUR}}$ values. It can be seen in Figure 9c that monthly HR values varied slightly from 0.22 to $0.37 \mathrm{~K} \mathrm{day}^{-1}$; however, the mean HR in the dry season of 2015 reached $0.62 \mathrm{~K} \mathrm{day}^{-1}$. The mean HR value found for the entire study period was $0.26 \pm 0.08 \mathrm{~K} \mathrm{day}^{-1}$ in the wet season and $0.37 \pm 0.13 \mathrm{~K} \mathrm{day}^{-1}$ in the dry season. These values are consistent with those reported by Procopio et al. (2004) for the study area. Studying two sites of AERONET (Abracos Hill and Alta Floresta), Procopio et al. (2004) found that aerosols form regional biomass burning caused variations between -5 and $-12 \mathrm{~W} \mathrm{~m}^{-2}$ for $\mathrm{SWARF}_{\mathrm{TOA}}$ and between -21 and $-74 \mathrm{~W} \mathrm{~m}^{-2}$ for $\mathrm{SWARF}_{\mathrm{SUR}}$. The differences between surface and atmospheric measurements are associated with an absorption of $16-62 \mathrm{~W} \mathrm{~m}^{-2}$ by the aerosol smoke layer, which induced an HR about 0.14-0.53 $\mathrm{K} \mathrm{day}^{-1}$.

On a regional scale, the variation of energy retained by the atmosphere has strong implications to changes in temperature and in the thermal structure of the atmosphere. This work addresses a period with few events of high aerosol loading, which contributes to a minimal HR variation in the study area. It was found that biomass burning aerosols caused variations of $-9.18 \pm 2.80 \mathrm{~W} \mathrm{~m}^{-2}$ in $\mathrm{SWARF}_{\mathrm{TOA}}$ and $-20.77 \pm 5.04 \mathrm{~W} \mathrm{~m}^{-2}$ in $\mathrm{SWARF}_{\text {SUR, }}$, which induced an HR of $0.37 \pm 0.13 \mathrm{~K} \mathrm{day}^{-1}$.

\section{Conclusion}

This study focused on quantifying the impact of aerosols on the shortwave radiation balance in a pristine forest inside the Central Amazon, under cloud-free conditions. In order to understand the radiative im- pacts of aerosol on local climate, SWARF in TOA, SUR, and ATM and associated atmospheric HR were calculated using the SBDART model. The analysis was performed using different time scales (monthly, seasonal, and annual) for a long period (2011-2017). The important conclusions of this study are:

1. From the measurements carried out in situ, the scattering and absorption evidenced the seasonal pattern of aerosol optical properties. Besides, the scattering showed a 10 -fold increase from the wet to the dry season. Absorption values also increased, but not at the same ratio. SSA values decreased by $10 \%$ at the beginning of the dry season (May-August) due to the strong absorption by black and brown carbon at the beginning of the biomass burning period.

2. When comparing SSA values in natural conditions of humidity within the atmospheric column (AERONET) with in situ measurements of SSA, it was observed that AERONET values have a higher average $(8.4 \pm 2.9 \%)$ with the greatest differences found in August and September (11.8\%). This is due to the increased emission of biomass burning in the atmospheric column. During the wet season, SSA medians were found to be above 0.99 , indicating the dominant effect of scattering on the radiation extinction. The water content in the atmospheric column considerably increased the SSA values.

3. Spectral analysis of AOD, SSA, and AP for the atmospheric column showed a smaller spectral dependency in the wet season compared to the dry season. AOD varied considerably in the dry season, and the higher values of Angstrom exponent in the dry season indicated that the addition of fine particles of biomass burning contributed to this variation.

4. The regression analysis of AERONET-SBDART at SUR and TOA revealed that SWARF values showed a relatively high correlation to the dry and wet seasons. For the whole period of analysis (without separation between dry and wet seasons) the $\mathrm{R}^{2}$ for $\mathrm{SWARF}_{\mathrm{SUR}}$ (AERONET-SBDART)

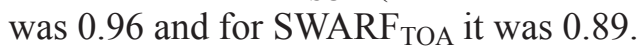

5. The averages for the season with highest aerosol loads (dry season) were $-9.18 \pm 2.80 \mathrm{Wm}^{-2}$ for $\mathrm{SWARF}_{\mathrm{TOA}},-20.77 \pm 5.04 \mathrm{~W} \mathrm{~m}^{-2}$ for SWARF- 
SUR, and $11.59 \pm 4.04$ for $\mathrm{SWARF}_{\mathrm{ATM}}$, inducing an HR of $0.37 \pm 0.13 \mathrm{~K} \mathrm{day}^{-1}$.

6. Considering that the impact of aerosols from biomass burning is given by the difference between SWARF in biomass burning conditions and SWARF under natural conditions (free of biomass burning), this study quantifies a net effect of $-5.52 \mathrm{~W} \mathrm{~m}^{-2}$ on top of the atmosphere for these aerosols, and $-3.66 \mathrm{~W} \mathrm{~m}^{-2}$ for the effect of natural (biogenic) aerosols in the study area.

\section{Acknowledgments}

This work was supported by Fundação de Amparo à Pesquisa do Estado de São Paulo (FAPESP 08/58100-2; 13/05014-0), Conselho Nacional de Desenvolvimento Científico (CNPq) and European Integrated FP6 project on Aerosol Cloud Climate and Air Quality Interactions (EUCAARI - 34684), under the scope of LBA experiment. The authors are grateful to NASA for providing AERONET data (http://aeronet.gsfc.nasa.gov/) and Conselho Nacional de Desenvolvimento Científico e Tecnológico (CNPQ) for financial support through 407998/2016-0 e 424915/2016-2.

\section{References}

Adesina AJ, Kumar KR, Sivakumar V. 2015. Variability in aerosol optical properties and radiative forcing over Gorongosa $\left(18.97^{\circ} \mathrm{S}, 34.35^{\circ} \mathrm{E}\right)$ in Mozambique. Meteorology and Atmospheric Physics 127: 217-228. https://doi.org/10.1007/s00703-014-0352-2

Alam K, Trautmann T, Blaschke T, Majid H. 2012. Aerosol optical and radiative properties during summer and winter seasons over Lahore and Karachi. Atmospheric Environment 50: 234-245. https://doi.org/10.1016/j. atmosenv.2011.12.027

Anderson TL, Ogren JA. 1998. Determining aerosol radiative properties using the TSI 3563 integrating nephelometer. Aerosol Science and Technology 29: 57-69. https://doi.org/10.1080/02786829808965551

Anderson TL, Covert DS, Wheeler JD, Harris J, Perry KD, Trost BE, Jaffe DJ, Ogren JA. 1999. Aerosol backscatter fraction and single scattering albedo: Measured values and uncertainties at a coastal station in the Pacific Northwest. Journal of Geophysical Research 104: 26793-26807. https://doi.org/10.1029/1999JD900172
Andreae MO, Artaxo P, Brandão C, Carswell FE, Ciccioli P, da Costa AL, et al. 2002. Biogeochemical cycling of carbon, water, energy, trace gases, and aerosols in Amazonia: The LBA-EUSTACH experiments. Journal of Geophysical Research 107(D20): 8066. https://doi. org/10.1029/2001JD000524

Andreae MO. 2007. Aerosols before pollution. Science 315: 50-51. https://doi.org/10.1126/science.1136529

Andreae MO, Acevedo OC, Araùjo A, Artaxo P, Barbosa CGG, Barbosa HMJ, et al. 2015. The Amazon Tall Tower Observatory (ATTO): Overview of pilot measurements on ecosystem ecology, meteorology, trace gases, and aerossols. Atmospheric Chemistry and Physics 15: 10 723-10 776. https://doi.org/10.5194/ acp-15-10723-2015

Artaxo P, Rizzo LV, Brito JF, Barbosa HMJ, Arana A, Sena ET, Cirino GG, Bastos W, Martin ST, Andreae MO. 2013. Atmospheric aerosols in Amazonia and land use change: From natural biogenic to biomass burning conditions. Faraday Discussions 165; 203-235. https:// doi.org/10.1039/C3FD00052D

Barbosa H, Barja BC, Pauliquevis T, Gouveia D, Artaxo P, Cirino G, Santos RM, Oliveira AB. 2014. A permanent Raman lidar station in the Amazon: Description, characterization, and first results. Atmospheric Measurement Techniques 7: 1745-1762. https://doi. org/10.5194/amt-7-1745-2014

Bibi H, Alam K, Bibi S. 2017. Estimation of shortwave direct aerosol radiative forcing at four locations on the Indo-Gangetic plains: Model results and ground measurement. Atmospheric Environment 163: 166181. http://dx.doi.org/10.1016/j.atmosenv.2017.05.043

Brito J, Rizzo LV, Morgan WT, Coe H, Johnson B, Haywood J, Longo K, Freitas S, Andreae MO, Artaxo P. 2014. Ground-based aerosol characterization during the South American Biomass Burning Analysis (SAMBBA) field experiment. Atmospheric Chemistry and Physics 14: 12069-12083. https://doi.org/10.5194/ acp-14-12069-2014

Capes G, Johnson B, Mcfiggans G, Williams PI, Haywood J, Coe H. 2008. Aging of biomass burning aerosols over West Africa: Aircraft measurements of chemical composition, microphysical properties, and emission ratios, Journal of Geophysical Research 113: 1-13, D00C15. https://doi.org/10.1029/2008JD009845

Carslaw KS, Boucher O, Spracklen DV, Mann GW, Rae JGL, Woodward S, Kulmala M. 2010. A review of natural aerosol interactions and feedbacks within the 
Earth system. Atmospheric Chemistry and Physics 10: 1701-1737. https://doi.org/10.5194/acp-10-1701-2010 Claeys M, Vermeylen R, Yasmeen F, Gómez-González Y, Chi X, Maenhaut W, Mészáros T, Salma I. 2012. Chemical characterization of humic-like substances from urban, rural, and tropical biomass burning environments using liquid chromatography with UV/vis photodiode array detection and electrospray ionisation mass spectrometry. Environmental Chemistry 9: 273284. https://doi.org/10.1071/EN11163

Davidson EA, Araujo AC, Artaxo P, Balch JK, Brown IF, Bustamante MMC, Coe MT, Defries RS, Keller M, Longo $\mathrm{M}$ et al. 2012. The Amazon basin in transition. Nature 481: 321-328. https://doi.org/10.1038/ nature 10717

De Sá SS, Rizzo LV, Palm BB, Campuzano-Jost P, Day DA, Yee LD, Wernis R, Isaacman-VanWertz G, Brito J, Carbone S, et al. 2019. Contributions of biomass-burning, urban, and biogenic emissions to the concentrations and light-absorbing properties of particulate matter in central Amazonia during the dry season. Atmospheric Chemistry and Physics 19: 7973-8001. https://doi.org/10.5194/acp-19-7973-2019

Dubovik O, Holben B, Eck TF, Smirnov A, Kaufman YJ, King MD, Tanre D, Slutsker I. 2002. Variability of absorption and optical properties of key aerosol types observed in worldwide locations. Journal of the Atmospheric Sciences 59: 590-608. https://doi. org/10.1175/1520-0469(2002)059<0590:VOAA$\mathrm{OP}>2.0 . \mathrm{CO} ; 2$

Dubuisson P, Buriez JC, Fouquart Y. 1996. High spectral resolution solar radiative transfer in absorbing and scattering media. Application to the satellite simulations. Journal of Quantitative Spectroscopy Radiative Transfer 55: 103-126. https://doi.org/10.1016/00224073(95)00134-4

Eck TF, Holben BN, Reid JS, Dubovik A, Smirnov OTONN, Slutsker I, Kinne S. 1999. Wavelength dependence of the optical depth of biomass burning, urban, and desert dust aerosols. Journal of Geophysical Research 104: 93-95. https://doi.org/10.1029/ 1999JD900923

Eck TF, Holben B, Sinyuk A, Pinker R, Goloub P, Chen H, Chatenet B, Li Z, Singh RP, Tripathi SN. 2010. Climatological aspects of the optical properties of fine/ coarse mode aerosol mixtures. Journal of Geophysical Research 115: D19205. http://dx.doi.org/10.1029/ 2010JD014002
Hallquist M, Wenger JC, Baltensperger U, Rudich Y, Simpson D, Claeys M, et al. 2009. The formation, properties, and impact of secondary organic aerosol: Current and emerging issues. Atmospheric Chemistry and Physics 9: 5155-5236. https://doi.org/10.5194/ acp-9-5155-2009

Holben B, Tanre D, Smirnov A, Eck T, Slutsker I, Abuhassan N, Newcomb W, Schafer J, Chatenet B, Lavenu F. 2001. An emerging ground-based aerosol climatology: Aerosol optical depth from AERONET. Journal of Geophysical Research 106: 12067-12097. https://doi. org/10.1029/2001JD900014

Hooda RK, Hyvärinen AP, Vestenius M, Gilardoni S, Sharma VP, Vignati E, Kulmala M, Lihavainen H. 2016. Atmospheric aerosols local-regional discrimination for a semi-urban area in India. Atmospheric Research 168: 13-23. http://dx.doi.org/10.1016/j.atmosres.2015.08.014 IBGE. 2015. Estimativas populacionais para os municípios e para as Unidades da Federação brasileiros em 16.05.2018. Technical report. Instituto Brasileiro de Geografia e Estatística. Available at: www.ibge.gov. bhttp://www.ibge.gov.br/home/estatistica/populacao/ estimativa2015/estimativa \{_\}dou.shtm. (accessed on May 22, 2018).

INPE. 2018. Portal do monitoramento de queimadas e incêndios. - Instituto Nacional de Pesquisas Espaciais. Available at: http://www.inpe.br/queimadas (accessed on May 22, 2018).

IPCC. 2013. Climate Change 2013: The physical science basis. Contribution of Working Group I to the Fifth Assessment Report of the Intergovernmental Panel on Climate Change. (Stocker TF, Qin D, Plattner G-K, Tignor M, Allen SK, Boschung J, Nauels A, Xia Y, Bex V, Midgley PM, Eds.).. Cambridge University Press, Cambridge, United Kingdom and New York, NY, USA. https://doi.org/10.1017/CBO9781107415324

Kaskaoutis DG, Gautam R, Singh RP, Houssos EE, Goto D, Singh S, Bartzokas A, Kosmopoulos PG, Sharma M, Hsu NC, Holben BN. 2012. Variability and trends of aerosol properties over Kanpur, northern India using AERONET data (2001-10). Environmental Research Letters 7: 024003. http://dx.doi.org/10.1016/j.agrformet.2018.04.018T1

Kaskaoutis D, Sinha P, Vinoj V, Kosmopoulos P, Tripathi S, Misra A, Sharma M, Singh R. 2013. Aerosol properties and radiative forcing over Kanpur during severe aerosol loading conditions. Atmospheric Environment 79: 7-19. https://doi.org/10.1016/j.atmosenv.2013.06.020 
Kaufman YJ, Tanré D, Boucher O. 2002. A satellite view of aerosols in the climate system. Nature 419:215-223. https://doi.org/10.1038/nature01091

Kaufman Y, Koren I, Remer L, Tanré D, Ginoux P, Fan S. 2005. Dust transport and deposition observed from the terra-moderate resolution imaging spectroradiometer (MODIS) spacecraft over the Atlantic Ocean. Journal of Geophysical Research 110. https://doi.org/10.1029/ 2003JD004436

Kumar S, Kumar S, Kaskaoutis D, Singh RP, Singh RK, Mishra AK, Srivastava MK, Singh AK. 2015. Meteorological, atmospheric and climatic perturbations during major dust storms over Indo-Gangetic Basin. Aeolian Research 17: 15-31. https://doi.org/10.1016/j. aeolia.2015.01.006

Laskin A, Laskin J, Nizkorodov SA. 2015. Chemistry of atmospheric brown carbon. Chemical Reviews 115: 4335-4382. https://doi.org/10.1021/cr5006167

Li Z, Lee KH, Wang Y, Xin J, Hao WM. 2010. First observation-based estimates of cloud-free aerosol radiative forcing across China. Journal of Geophysical Research 115. https://doi.org/10.1029/2009JD013306

Lin P, Aiona PK, Li Y, Shiraiwa M, Laskin J, Nizkorodov SA, Laskin A. 2016. Molecular characterization of brown carbon in biomass burning aerosol particles. Environmental Science \& Technology 50: 11815-11824. https://doi.org/10.1021/acs.est.6b03024

Liou KN. 2002. An introduction to atmospheric radiation. Academic Press.

Martin ST, Andreae MO, Althausen D, Artaxo P, Baars H, Borrmann S, et al. 2010. An overview of the Amazonian Aerosol Characterization Experiment 2008 (AMAZE-08). Atmospheric Chemistry and Physics 10: 11415-11438. https://doi.org/10.5194/acp-10-11415-2010

Martin ST, Artaxo P, Machado LAT, Manzi AO, Souza RAF, Schumacher C, Wang J, Andreae MO, Barbosa HMJ, Fan J et al. 2016. Introduction: Observations and Modeling of the Green Ocean Amazon (GoAmazon2014/5), Atmospheric Chemistry and Physics 16: 4785-4797. https://doi.org/10.5194/acp-16-4785-2016

Müller T, Henzing JS, de Leeuw G, Wiedensohler A, Alastuey A, Angelov H, et al. 2011. Characterization and intercomparison of aerosol absorption photometers: Result of two intercomparison workshops. Atmospheric Measurement Techniques 4: 245-268. https:// doi.org/10.5194/amt-4-245-2011

Palácios RS, Romera KS, Curado LFA, Banga NM, Rothmund LD, Sallo FS, Morais D, Santos ACA, Moraes
TJ, Morais FG et al. 2020. Long term analysis of optical and radiative properties of aerosols in the Amazon basin. Aerosol Air Quality Research 20: 139-154. https:// doi.org/10.4209/aaqr.2019.04.0189

Patadia F, Gupta P, Christopher SA, Reid JS. 2008. A multi-sensor satellite-based assessment of biomass burning aerosol radiative impact over Amazonia. Journal of Geophysical Research 113: D12214. https://doi. org/10.1029/2007JD009486

Petzold A, Schloesser H, Sheridan P, Arnott WP, Ogren J, Virkkula A. 2005. Evaluation of multiangle absorption photometry for measuring aerosol light absorption. Aerosol Science and Technology 39: 40-51. https:// doi.org/10.1080/027868290901945

Pokhrel RP, Wagner NL, Langridge JM, Lack DA, Jayarathne T, Stone EA, Stockwell CE, Yokelson RJ, Murphy SM. 2016. Parameterization of single-scattering albedo (SSA) and absorption Ångström exponent (AAE) with $\mathrm{EC}=\mathrm{OC}$ for aerosol emissions from biomass burning. Atmospheric Chemistry and Physics 16: 9549-9561. https://doi.org/10.5194/acp-16-9549-2016

Pöschl U, Martin ST, Sinha B, Chen Q, Gunthe SS, Huffman JA, Borrmann S, Farmer DK, Garland RM, et al. 2010. Rainforest aerosols as biogenic nuclei of clouds and precipitation in the Amazon. Science 329: 1513-1516. https://doi.org/10.1126/science. 1191056

Prasad AK, Singh S, Chauhan SS, Srivastava MK, Singh RP, Singh R. 2007. Aerosol radiative forcing over the Indo-Gangetic plains during major dust storms. Atmospheric Environment 41: 6289-6301. https://doi. org/10.1016/j.atmosenv.2007.03.060

Procopio AS, Remer LA, Artaxo P, Kaufman YJ, Holben BN. 2003. Modeled spectral optical properties for smoke aerosols in Amazonia. Geophysical Research Letters 30: 2265. https://doi.org/10.1029/2003GL018063

Procopio AS, Artaxo P, Kaufman YJ, Remer LA, Schafer JS, Holben BN. 2004. Multiyear analysis of amazonian biomass burning smoke radiative forcing of climate. Geophysical Research Letters 31: L03108. https://doi. org/10.1029/2003GL018646

Rajeev K, Ramanathan V. 2001. Direct observations of clear-sky aerosol radiative forcing from space during the Indian Ocean Experiment. Journal of Geophysical Research 106, 17,221-17,235. https://doi.org/10.1029/ 2000JD900723

Ramanathan V, Crutzen JP, Kiehl T, Rosenfeld D. 2001. Aerosols, climate, and the hydrological cycle. Science 294: 2119. https://doi.org/10.1126/science.1064034 
Rap A, Scott CE, Spracklen DV, Bellouin N, Forster PM, Carslaw KS, Schmidt A, Mann G. 2013. Natural aerosol direct and indirect radiative effects. Geophysical Research Letters 40: 3297-3301. https://doi. org/10.1002/grl.50441

Reid JS, Eck TF, Christopher SA, Koppmann R, Dubovik O, Eleuterio DP, Holben BN, Reid EA, Zhang J. 2005. A review of biomass burning emissions part III: Intensive optical properties of biomass burning particles. Atmospheric Chemistry and Physics 5: 827-849. https://doi.org/10.5194/acp-5-827-2005

Rizzo LV, Correia AL, Artaxo P, Procppio AS, Andreae MO. 2011. Spectral dependence of aerosol light absorption over \newline the Amazon Basin. Atmospheric Chemistry and Physics 11: 8899-8912. https://doi. org/10.5194/acp-11-8899-2011

Rizzo LV, Artaxo P, Müller T, Wiedensohler A, Paixão M, Cirino GG, Arana A, Swietlicki E, Roldin P, Fors EO et al. 2013. Long term measurements of aerosol optical properties at a primary forest site in Amazonia. Atmospheric Chemistry and Physics 13: 2391-2413. https://doi.org/10.5194/acp-13-2391-2013

Rizzo LV, Roldin P, Brito J, Backman J, Swietlicki E, Krejci R, Tunved P, Petäjä T, Kulmala M, Artaxo P. 2018. Multi-year statistical and modeling analysis of submicrometer aerosol number size distributions at a rainforest site in Amazonia. Atmospheric Chemistry and Physics Discussion. https://doi.org/10.5194/acp-2018-55

Roger JC, Mallet M, Dubuisson P, Cachier H, Vermote E, Dubovik O, Despiau S. 2006. A synergetic approach for estimating the local direct aerosol forcing: Applications to an urban zone during the ESCOMPTE experiment. Journal of Geophysical Research 111. https://doi. org/10.1029/2005JD006361

Saleh R, Hennigan CJ, McMeeking GR, Chuang WK, Robinson ES, Coe H, Donahue NM, Robinson AL. 2013. Absorptivity of brown carbon in fresh and photo-chemically aged biomass-burning emissions. Atmospheric Chemistry and Physics 13: 7683-7693. https://doi.org/10.5194/acp-13-7683-2013

Saleh R, Robinson ES, Tkacik DS, Ahern AT, Liu S, Aiken AC, Sullivan RC, Presto AA, Dubey MK, Yokelson RJ et al. 2014. Brownness of organics in aerosols from biomass burning linked to their black carbon content. Nature Geoscience 7: 647. https://doi.org/10.1038/ ngeo 2220

Saturno J, Holanda BA, Pöhlker C, Ditas F, Wang Q, Moran-Zuloaga D, et al. 2018. Black and brown carbon over central Amazonia: Long-term aerosol measurements at the ATTO site. Atmospheric Chemistry and Physics 18: 12817-12843. https://doi.org/10.5194/ acp-18-12817-2018

Schafer JS, Eck TF, Holben BN, Artaxo P, Duarte AF. 2008. Characterization of the optical properties of atmospheric aerosols in Amazônia from long-term AERONET monitoring (1993-1995 and 1999-2006). Journal of Geophysical Research 113: 1-16. https:// doi.org/10.1029/2007JD009319

Scott CE, Rap A, Spracklen DV, Forster PM, Carslaw KS, Mann GW, Pringle K J, Kivekäs N, Kulmala M, Lihavainen H, Tunved P. 2014. The direct and indirect radiative effects of biogenic secondary organic aerosol. Atmospheric Chemistry and Physics 14: 447-470. https://doi.org/10.5194/acp-14-447-2014

Scott CE, Arnold SR, Monks SA, Asmi A Paasonen P, Spracklen DV. 2018a. Substantial large-scale feedback between natural aerosols and climate. Nature Geoscience 11: 44-48. https://doi.org/10.1038/s41561017-0020-5

Scott CE, Monks SA, Spracklen DV, Arnold SR, Forster PM, Rap A, et al. 2018b. Impact on short-lived climate forcers increases projected warming due to deforestation. Nature 9: 157. https://doi.org/10.1038/ s41467-017-02412-4

Sena ET, Artaxo P, Correia AL. 2013. Spatial variability of the direct radiative forcing of biomass burning aerosols and the effects of land use change in Amazonia. Atmospheric Chemistry and Physics 13: 1261-1275. https://oi.org/10.5194/acp-13-1261-2013

Sena ET, Artaxo P. 2015. A novel methodology for largescale daily assessment of the direct radiative forcing of smoke aerosols. Atmospheric Chemistry and Physics 15, 5471-5483. https://doi.org/10.5194/acp-15-54712015

Singh A, Tiwari S, Sharma D, Singh D, Tiwari S, Srivastava AK, Rastogi N, Singh A. 2016. Characterization and radiative impact of dust aerosols over northwestern part of India: A case study during a severe dust storm. Meteorology and Atmosphere Physics 128: 779-792. https://doi.org/10.1007/s00703-016-0445-1

Takemura T, Nakajima T, Dubovik O, Holben BN, Kinne S. 2002. Single-scattering albedo and radiative forcing of various aerosol species with a global three-dimensional model. Journal of Climate 15: 333-352. https:// doi.org/10.1175/1520-0442(2002)015<0333:SSAARF $>2.0 . C O ; 2$ 
Tuch TM, Haudek A, Müller T, Nowak A, Wex H, Wiedensohler A. 2009. Design and performance of an automatic regenerating adsorption aerosol dryer for continuous operation at monitoring sites. Atmospheric Measurement Techniques 2: 417-422. https://doi. org/10.5194/amt-2-417-2009
Valenzuela A, Olmo F, Lyamani H, Anton M, Quirantes A, Alados-Arboledas L. 2012. Aerosol radiative forcing during African desert dust events (2005-2010) over Southeastern Spain. Atmospheric Chemistry and Physics 12: 10331-10351. https://doi.org/10.5194/ acp-12-10331-2012 